U

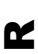

129

山

$\boldsymbol{\infty}$

\title{
desarrollo productivo
}

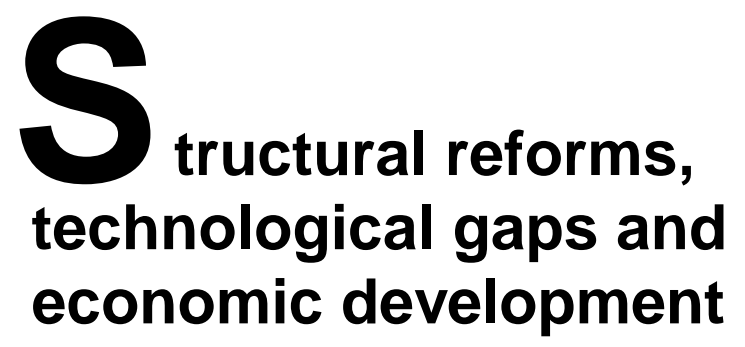

A Latin American Perspective

Mario Cimoli and Jorge Katz

Division of Production, Productivity and Management

Restructuring and Competitiveness Network

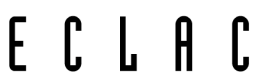

Santiago, Chile, August, 2002 

This paper has been presented at the DRUID-Nelson and Winter conference, held in Aalborg, 12-15 of June 2001. We are indebt with C. Edquist, K. Smith and $\mathrm{M}$. Teubal for their constructive suggestions when this paper was presented at the Nelson and Winter conference. We are also grateful to W. Peres, M. di Maio and P. Martinez for their sights and suggestions.

The views expressed in this document, which has been reproduced without formal editing, are those of the author and do not necessarily reflect the views of the Organization.

\section{United Nations Publication}

LC/L.1775-P

ISBN: 92-1-121366-5

ISSN printed version:1020-5179

ISNN online version:1680-8754

Copyright (C) United Nations, August 2002. All rights reserved

Sales No.: E.02.II.G.89

Printed in United Nations, Santiago, Chile

Applications for the right to reproduce this work are welcomed and should be sent to the Secretary of the Publications Board, United Nations Headquarters, New York, N.Y. 10017, U.S.A. Member States and their governmental institutions may reproduce this work without prior authorization, but are requested to mention the source and inform the United Nations of such reproduction. 



\section{Contents}

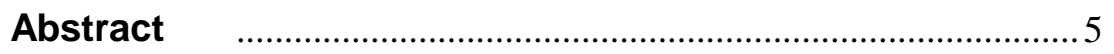

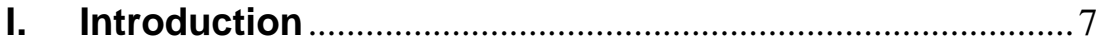

II. An evolutionary approach of the transition process

to a global incentive regime.

III. A simple macro-to micro model of the stabilization cum structural reform process

IV. A new pattern of production specialization ................. 23

V. Structural reforms and intro-industry restructuring process

VI. External versus domestic 'sources' of technical

Progress.

VII. Increasing returns to scale and the technological gap 35

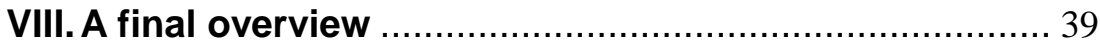

Bibliography ......................................................... 41

Serie Desarrollo Productivo: Issues Published ................. 45 


\section{Tables}

Table 1 Changes in the relative weight of industrial sectors in total manufacturing output (1970-1996)

\section{Figures}

Figure 1 Adjustment phases and macro-micro interaction.................................................. 17

Figure 2 Relative labor productivity gap vis a vis US industries according to factor intensity

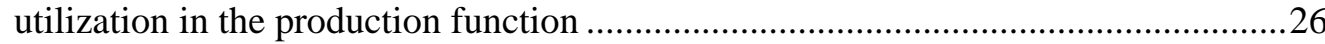

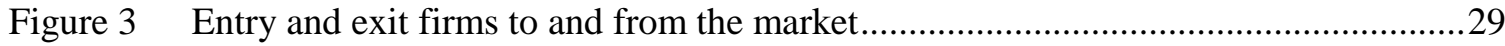

Figure 4 Substitution of local technological sources in a manufacturing plant .........................33

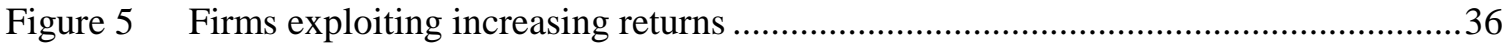

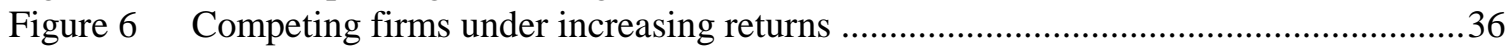

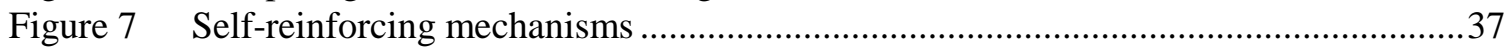

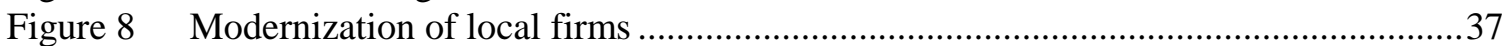




\section{Abstract}

This paper explores the impact recent structural reforms have had on macro-to-micro linkages, as well as upon the pattern of production specialization, the entry and exit of firms during the adjustment process, and the 'sources' of technical change in the present more open and de-regulated Latin American scenarios. Having described some of the above one final question emerges quite clearly: is the new 'market-oriented' growth paradigm sustainable in the long run? The story hereby presented suggests that the present pattern of production specialization - strongly biased in favor of industries featuring low domestic knowledge generation and value added content - and the inhibition of local R\&D and engineering activities resulting from the rapid expansion of internationally integrated production systems are pushing Latin American economies into a 'low growth trap' from which it might turn up to be difficult to escape exclusively on the basis of free market principles. New institutions and new forms of public-to-private interaction in the field of technology generation and dissemination seem to be a sine qua non condition for faster productivity growth and for the improvement of international competitiveness. Both of these seem to be urgently needed if the long-term sustainability of recent structural reforms is to be maintained in the future. 



\section{Introduction}

Launching the Ford Taunus to the Argentine market, back in 1974, demanded some 300 thousand hours of domestic engineering efforts carried out by a local team of 120 professionals employed by Ford's Engineering Department. These people were responsible for generating a steady flow of incremental units of production organization and engineering knowledge required for the adaptation of the German-designed 'blue prints' to the local environment, to the available raw materials, to the idiosyncrasies of the Argentine plantnot bigger than $10 \%$ of Ford's production facilities in Germany-to the technological capabilities of domestic subcontractors producing parts and components for the referred vehicle, and so forth. One and a half year of domestic engineering activities were required in order to introduce changes and adaptations in the design of the vehicle, in production planning and organization routines, in the technologies employed by local subcontractors for the production of parts and components, etc before the car could be brought to the market. Domestic content for such car was close to $90 \%$ of the total value of the vehicle. Nearly 400 subcontractors supplied parts and components under Ford's stringent specifications. Direct expenditure in the above mentioned engineering efforts was in the order of 6 million U\$S dollars in activities which would normally classify as 'development' expenditure in contemporary R\&D statistics. The car was basically aimed for the domestic market, but a number of the incremental units of knowledge thereby attained were made available to other Ford subsidiaries around the world featuring similar production and industrial organization conditions than those prevailing in Argentina. 
Product prototypes were prepared and tested, special dyes and cutting tools had to be designed and constructed 'in house', and so on.

The production organization model and the technological 'regime' associated to the production of the Ford Taunus in Argentina-which describe at its best the functioning of this industry and its 'localized' technological 'regime' in the above mentioned country in the 1970's and 1980's - no longer exist to-day. Ford Argentina is now part of a world-wide integrated production system, working 'on-line' with other Ford subsidiaries around the world, assemblingwith less than $50 \%$ local content, and with no domestic engineering efforts whatsoever-a 'worldcar' which has become something of a 'commodity'. Though the productivity gap between the Argentine automobile industry and the world's frontier can be shown to be somewhat smaller than in the past, Argentina's vehicle industry is still far behind international standards. It currently exports close to a quarter million vehicles per annum to Brazil under Mercosur preferential conditions but it could not capture new markets in recent years even in spite of the fact that it is currently operating at less than $60 \%$ of installed capacity. Moreover, it has now become more of an assembly operation of imported parts and components with little, if any, incidence upon the development of domestic technological capabilities and mechanical engineering skills. It's wellestablished synergies and externalities vis a vis the local metalworking industry no longer can be argued to be significant.

The above story encapsulates a complex set of issues related to the economics of innovation in peripheral economies, to the 'catching up' and 'lagging behind' of specific countries and industries in the process of economic growth. In particular, it unveils major questions concerning the accumulation of domestic technological capabilities in developing countries and the gap LDCs exhibit with respect to the international productivity frontier, all topics of great importance in the contemporary academic and policy debate.

One of our main objectives in the present paper is to stress the major role that the micro-tomacro interdependencies play in shaping up technological behaviour and innovation in developing economies, particularly so in the Latin American ones (Katz 1986, 1987, 2000 and Cimoli 2000). Very often such interdependencies are left aside by scholars writing on technical change and innovation in developed industrial countries, were the assumption of a 'well behaved' macro can be more realistically held than in the case of developing economies. As far as Latin America is concerned it is quite clear that a much more turbulent macro induces long term 'defensive' and opportunistic attitudes at the level of individual firms and that such attitudes explain why industries and countries attain a less than satisfactory rate of technical progress and productivity growth than their competitors in more stable macroeconomic scenarios. In a similar vein, the sustainability of macro stability requires complementary conditions to be attained at the meso and micro level. For example, the long term sustainability of the exchange rate and of balanced external accounts strongly depend upon the sectoral pattern of production specialization and productivity growth, closing back the micro-to-macro loop frequently overlooked in the current literature on innovation and technical change.

We argue here that the association between the macro performance and the accumulation of domestic technological capabilities has to be analyzed at the light of the market-oriented reforms introduced by most Latin American countries in the 1990's and the global set of incentives provided by a higher degree of integration in the world's market place. Such changes in the 
institutional and regulatory framework, which involved a radical reduction of tariff protection, a massive privatization of services and a quite unconditionally acceptance of trade and intellectual property right agreements, have drastically impacted each sector and market ${ }^{1}$.

New patterns of production specialization and trade have emerged, with knowledge intensive industries loosing ground within GDP while non-tradable activities and natural resource processing industries and 'maquila'-type assembly operations (catering mostly for US markets), have gained participation. Dramatic changes in the 'sources' of technical change and productivity growth have occurred, with a rapidly increasing share of external 'sources' emerging at the expense of domestic ones. Pari pasu with the development of new forms of articulation of domestic firms and consumers with foreign sources of know how and with the rapid diffusion of information technologies, the pattern of accumulation of technological capabilities has been changing in structure and performance. As a result of the above the relative technological gap with the world's 'best practice' frontiers has become smaller in highly 'localized' and specific areas of each economy (such as telecommunication services, Internet access, or energy production and distribution), but globally such gap remains still dramatically high, even after long years of trade liberalization and market deregulation efforts.

In the present paper we try to develop a simple appreciative model exploring some of the above issues. We also try to identify the more crucial policy questions that our story poses to the profession in relation to innovation, technological 'regimes' and long term economic growth of peripheral countries. Section two introduces a brief view as to how the evolutionary approach should be adapted to analyse the impact of recent structural reforms upon the specialization pattern and technological capabilities accumulated in so called developing economies. A simple macro-tomicro model of the stabilization cum structural reform process is presented in section three. Here, we put the focus on the relationship between the macro and micro components of the model and the importance of the latter for the long-term sustainability of the growth process. Sections four and five are devoted to investigate in more detail recent changes in the pattern of production specialisation of the Latin American economies and the relationship such changes have with the exit and entry of firms. Under the assumption that firms are repositories agents of knowledge, establishing linkages and building up production and technology generation networks with other firms and institutions (Nelson and Winter 1982, Winter 1984, Nelson 1995), we develop - in sections six and seven - a simple model to examine the relationship between structural reforms and the 'sources' of technological change, and how the trade off between local and external 'sources' of technology has been changing in recent years as a result of the rapid globalization of the world's economy. The last section summarises our conclusions.

\footnotetext{
${ }^{1}$ The radical change from a closed to a more open and deregulated economy has impacted each sector and firm. By explicitly referring to this perspective, a change in the institutional and regulatory regimes and, consequently, in the set of prices and incentives affects both the competitive relationships and the modes of accumulating technological capabilities. As a matter of fact, it is possible to differentiate within sectors and industries on the basis of their competitive boundaries, from the more local to the national and up to the international competition arenas. Not only are competitive relationships in terms of products relevant, the modalities in which firms compete regarding the acquisition of equipments, intermediate commodities, etc. from local or foreign suppliers are significant as well. (Breschi and Malerba 1997, Cimoli 2000 and Katz 2000)
} 



\section{A evolutionary approach of the transition process to a global incentive regime}

More than two decades have already passed since the first attempts were made in Latin America to move towards a development strategy that was more open to external competition and more deregulated, with less participation of the State as a producer of goods and services. Efforts in this direction began in Chile in the early 1970s and in Argentina later in the same decade; Mexico and Costa Rica followed suit in the 1980s. Brazil appears as a late reformer, initiating market-oriented reforms only in the early 1990s. Such a major change in the global incentive regime prompted enormous macro-, meso- and microeconomic changes. The production structure and the institutional and regulatory framework of each one of the Latin American economies is currently in the process of a deep, long-term structural transformation.

Most of the available literature on the impact of recent structural reforms in Latin America is macroeconomic in nature. It consequently fails to capture the enormous role meso and microeconomic forces, as well as institutional and technological variables have, in influencing the adjustment process of each country and industry to a new incentive regime. Macroeconomic analysis is 
solely concerned with how the economy returns to a new equilibrium growth path, after a short term disequilibrium episode, but is not particularly worried by technological and organizational features of the new production structure, nor for who wins and who loses during the transition process. It is basically the equilibrium of fiscal and external aggregates that the model regards as crucial, and not what the rate of productivity growth and international competitiveness of the economy are likely to be in the future. Neither do equity considerations normally appear as fundamental issues in the search for macroeconomic equilibrium.

We argue here that looking at the current Latin American scenario as from 'conventional' lens is highly misleading and can lead us in the wrong direction both in terms of diagnosis and of policy design and formulation. Productivity growth has not been fast enough, nor has the restructuring of the pattern of production specialization involved high value added activities, for the countries in the region to attain a significant degree of improvement in their international competitiveness. The international technological gap has been reduced in highly specific and 'localized' areas of the economy but the income gap with more mature industrial societies has remained as high- or worse - than before. Moreover, the benefits of modernization have been very unevenly distributed throughout the local society. Many production activities have been seriously disrupted by trade liberalization and by the massive inflow of imports, particularly so in technology intensive fields, which have rapidly proceeded toward the de-verticalization of their production organization technologies, substituting domestically-produced intermediate inputs by cheaper (and sometimes better) imported ones, reorganizing themselves more as assembly-type operations based on a much higher unit import content. The heterogeneity of responses has been quite dramatic, not only across sectors of production, but also across individual firms within narrowly defined industries. Thus, failure and success tend to appear next to each other even within specific production activities. The share of 'large' firms - either local subsidiaries of transnational corporations or domesticallyowned conglomerates - in gross domestic product (GDP) has significantly increased during the adjustment process, while countless SMEs have been forced to exit the market altogether. Macro and micro interactions during the course of the stabilisation process and the impact of ubiquitous market failures - particularly in factor markets - have had a strong impact upon the pattern of production specialization - stongly biased against domestic value added - than what 'main stream' economists a priori expected.

Although the impact of recent structural reforms upon the domestic pattern of technological accumulation, growth and productivity certainly differs across countries ${ }^{2}$, a 'generic' appreciative model of the above is presented here, highlighting some 'stylized facts' of the situation probably present in one way or another in most of the countries under examination ${ }^{3}$. The approach we follow here draws extensively on Schumpeter's metaphor of the 'creative destruction' processes and the analytical contribution of Nelson and Winter (1982) for the understanding of the "evolutionary pattern of economic change". In our view, Latin America is currently undergoing fundamental changes in the model of production organization, as well as in its institutional and regulatory environment, leaving behind forty years of 'inward-oriented' 'state-lead'growth. Such changes are

\footnotetext{
2 The reasons for that are rather obvious. First, the countries differ in their accumulated technological capabilities and in the degree of technological maturity attained prior to recent structural reforms, such that their responses were bound to be different. Second, they initiated the processes of trade liberalization and market deregulations at different points in time, and were therefore differently affected by the ups and downs of international capital markets and trade cycles. Finally, they all differ, too, in the depth and internal consistency of their macroeconomic stabilization cum structural reforms policies, as well as in the extent to which they received external support during the implementation of these measures.

${ }^{3}$ The reader should notice that we are talking about the joint impact of macroeconomic stabilization efforts and structural reform policies. Even though in the 1980's both such actions were undertaken jointly by most countries in the region, this has not been the case in the 1990 's when the later were implemented in much more stable macroeconomic scenarios.
} 
inducing a complex process of 'destruction' of deeply-rooted forms of production organization and of institutions, and gradually (and painfully) forcing the establishment of a new, more competitive, outward-oriented and de-regulated incentive regime, whose basic structural features are still on the making. Extreme faith from Latin American policy makers - and a great deal of pressure from outside, one should add - are inducing them to believe that A.Smith's 'invisible hand' is capable of guiding an optimal transition between development regimes. Casual observation, however, indicates that such transition induces highly heterogeneous responses across industries, regions and firms and that we lack an integrated micro-to-macro theory which could help us to understand the role economic and technological variables play in explaining the way different firms, industries and regions adapt themselves to the new rules of the game. We now turn to a more formal examination of the above. 



\section{A simple macro-to-micro model of the stabilization cum structural reform process}

We shall now examine the impact of a change in the macroeconomic incentive regime aiming at stabilizing the economy, on the one hand, and of introducing structural reforms, on the other. Such a policy package involves a drastic change in the regulatory and incentive regimes (including, tariff protection, patent legislation, property rights on natural resources, and so forth) aiming to open the economy to foreign competition ${ }^{4}$. The central objective of the policy package - which includes monetary, fiscal and income policies, as well as changes in the regulatory and institutional 'regime' - is that of reducing aggregate demand and imports while simultaneously expanding exports, together with exposing local firms to more external 'contestability'.

The impact of the above-mentioned policy interventions can be imagined to proceed through three different stages in which macro, meso and microeconomic changes take place simultaneously in the economy, as we move from a highly uncertain and turbulent economic

\footnotetext{
${ }^{4}$ Such policy and regulatory changes are normally undertaken in a situation in which both fiscal and external accounts have moved significantly out of equilibrium. The policies are also inforced with the purpose of inducing more competition throughout the economy.
} 
environment toward a more predictable and close-to-equilibrium one. It is the interdependencies between macro and micro forces (Katz (2000)), as well as the co-evolution of economic, institutional and technological variables, and their relation to entry and exit, investment, innovation and productivity growth, as well as to changes in sectoral competitive and technological 'regimes' (Winter (1984), Breschi and Malerba (1997), Malerba and Orsenigo (1997), Cimoli (2000)), that we want here to explore.

The first 'stage' in the adjustment process finds the economy in an extreme degree of macroeconomic turbulence, with its fiscal and external accounts out of control, and with savings, investment and the level of production significantly contracting. Such stage has been described in the literature as a situation of 'stag-flation' in which prices are increasing and, simultaneously, output, production and employment are contracting. Many firms are forced to leave the market under the impact of as contracting demand and of increasing imports. The change in the global incentive regime is introduced with the purpose of bringing the 'fundamentals' of the economyexchange rate, interest rate, real wages- closer to equilibrium, hoping that by so doing expectations and entrepreneurial 'animal spirits' could be improved.

It is when the above 'macro' prices get more under control and the new incentive regime has been more "internalised" by economic agents, that we can talk about the economy entering into a second stage in its adjustment process. The rate of inflation, the fiscal deficit, external accounts, begin to show signs of improvement, indicating that individual economic agents are responding to the monetary, fiscal, income and regulatory policies applied by the economic authorities. Finally, a third stage can be imagined to obtain when the 'fundamentals' of the economy consolidate, with savings and investment growing once again, new firms entering the market and growth catching up with its long term trend, with a new set of relative prices and a new macropolicy and regulatory regime prevailing in the economy.

Figure 1 attempts to describe such process in a simple way. On the right hand side, we show how aggregate output contracts first, and expand later on, during the adjustment episode. On the left hand side, on the other hand, we depict changes in the price level as well as in aggregate demand and supply during the adjustment process. The aggregate demand curve has a upward slope, while the aggregate supply curve is vertical for all levels of output under the hypothesis of constant returns to scale (Asimakopulos 1977, Kalecki 1990, Lavoie 1977 and Kriesler 1988). 


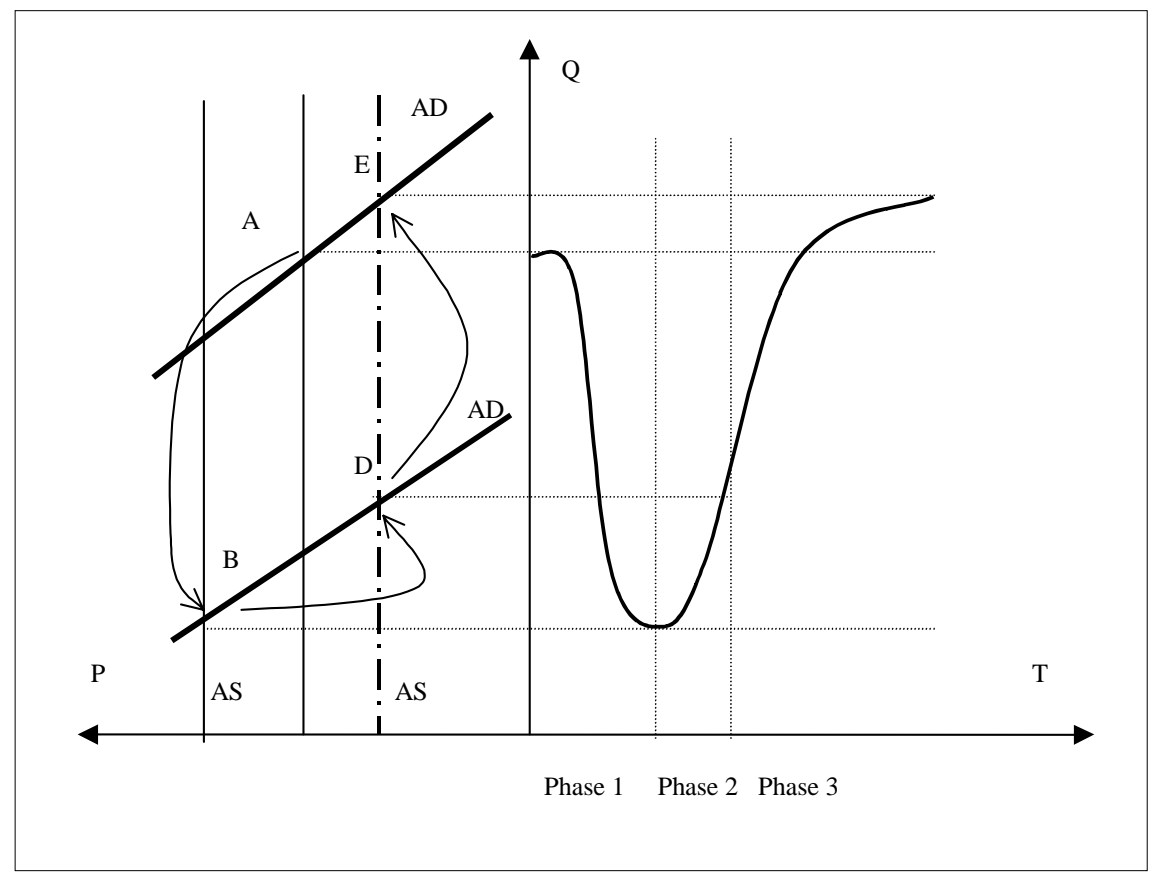

During Phase 1 of the adjustment process the economy suffers from an extreme degree of disequilibrium, with its fiscal and external accounts way out of control. Being strongly underfinanced the public sector is forced to borrow from the Central Bank, from local capital markets or from external sources. In order to do that it has to push the interest rate upward to get access to funds in an economic environment that is growing increasingly uncertain and risky by the day $^{5}$. Under such conditions, the economy gradually settles into a pattern of recession and inflation, with prices going up — as depicted on the left-hand side of the diagram - and aggregate demand contracting. During the stag-flation process the economy moves from A to B. Such scenario is characterised by lower utilization of production capacity, with many firms exiting the market and real wages contracting. Domestic markets become smaller both as a result of lower real wages and of a higher rate of unemployment.

The initial phase of intense macroeconomic uncertainty and imbalance tends to be followed by a second phase in which stabilization forces begin to operate. The loss of reserves is brought under control. The fiscal deficit and the rate of inflation become smaller and the interest rate begin to fall. The trade deficit declines as imports get smaller and exports tend to expand. In Figure 1, this process is captured by the movement along the demand curve form $\mathrm{B}$ to $\mathrm{D}$.

This induces firms to look for exports as a way of maintaining a high rate of utilization of their installed capacity. However, for our own purposes it is important to notice that the impact of the adjustment process is bound to be different in different sectors of economic activity, and even

\footnotetext{
${ }^{5}$ Consider that in scenarios of this sort the daily rate of inflation can reach 1 or even $2 \%$ and try to imagine what production planning and organization mean under such circumstances. In one way or other this was the situation in Brazil, Argentina or Chile back in the early 1980's.
} 
in different firms, within particular industries. Such differences are normally overlooked by conventional macroeconomic discussions of the adjustment process.

We can a priori expect that a better reaction in this direction is attained by natural resource processing industries which operate closer to the "natural' comparative advantages of the economy and could therefore exploit better their cost differentials with international producers. On the contrary, technology intensive sectors producing, say, capital goods for the domestic markets under tariff protection and featuring a rather high unit import content are the more severely affected by the devaluation of the local currency and by the contraction of aggregate investment. These industries normally operate well behind the international 'state of the art' and therefore find it more difficult rapidly to move into exports. Domestically produced pieces of machinery are also hard to sell internationally as a result of the lack of competitive financing from local banks, as normally available to capital goods producers from more developed industrial countries.

Such events provide clear signals that a gradual recovery is underway but cheaper (and sometimes, better) imports of foreign products now begin to flood the local markets as tariffs have been reduced and importers have had enough time to build up their distribution channels locally. Imports now become a major source of competition for local firms. In that context, domestic companies are forced to lower production costs and this they do mostly by re-organizing production processes and reducing their demand for labor, but without strongly committing themselves to the erection of new production capacity or to the introduction of 'major' technological changes. The signals of improvement in the macro 'fundamentals' of the economy are still very recent and the costs of the 'stag-flation' period still persist in every firm's memory for them easily to commit themselves to long term, risky decisions.

It is only in the third phase of the adjustment process that the economy shows clear strength and that growth tends to accelerate in the context of the new set of relative prices and regulatory institutions. Under the new conditions entrepreneurs become proactive again. The country's international risk rating tends to fall, and savings and investment, as well as foreign direct investment start to grow once again.

Here, we can imagine two possible outcomes. The first one relates to the case in which the stabilization cum structural reforms programme succeeds and the economy returns to a long term 'virtuous' path in which savings and investment significantly expand, new production capacity is being built and unemployment is rapidly reduced. This process is described in the Figure by the transition from D to E. We can think of this 'virtuous' sequence from 'stag-flation' to full employment growth as being close to the Chilean experience of the late 1980's and early 1990's in which the country managed to return to a steady $7 \%$ annual growth rate, reducing its $22 \%$ rate of unemployment in the early 1980's to 6\% in the mid 1990's. Chile could maintain steady growth under such conditions for nearly one and a half decades ${ }^{6}$.

\footnotetext{
${ }^{6}$ During the $80 \mathrm{~s}$ and beginning of the $90 \mathrm{~s}$, its extraordinary performance has been based on an export-led growth pattern and an international specialisation oriented to natural resources and standardised "commodities" with higher capital-intensity production process (copper, fishmeal, cellulose, etc ). This result is supported also by an investment boom in natural resource industries -particularly in cooper mining- and a structural transformation of production process. More recently, the country growth performance has not been so strong and its structural difficulties of creating new employment, diversifying into manufacturing exports and/or developing local linkages indicate that Chile is not more an exception in the region. Its prosperous growth path of the 1990's seems to be exhausted (Moguillansky, 1999).
} 
The second case describes the situation in which the new macropolicy regime fails to consolidate and the economy falls into a low growth trap in which the new set of macroeconomic prices becomes unsustainable. This could be the consequence of strong inconsistencies in the adjustment programme - for example, an overvalued exchange rate which makes export growth rather difficult to attain - or could also result from unexpected external shocks such as, for example, the devaluation of the Brazilian currency for the Argentine economy, in the late 1990's . Under such circumstances the economy can be expected to enter into a new stage of macroeconomic disequilibrium and disarray, with the degree of uncertainty rapidly gaining ground once again. From the point of view of the model presented in Figure 1 the economy returns from D to B. In such circumstances there is no other option but to start the adjustment process all over again with a new change in 'macro prices'. It is in that sense that, for example, Argentine real wages became rather 'high' relatively to the new Brazilian rate of exchange when Brazil devalued its local currency by $30 \%$ in 1999. Argentine exports to Brazil - close to $40 \%$ of Argentina's total exports - could not be subtained under the new circumstances and a new adjustment process had to be inforced by Argentina.

In a recent book by Ricardo Ffrench-Davis and Stephany Griffith-Jones the authors identify a number of macroeconomic circumstances, both internal and external to any given country, that influence the process of structural adjustment and that can cause macroeconomic stabilization efforts to fail. These authors detect at least five reasons why this might happen: "First, external capital flows should consistently go to augment aggregate investment and not be diverted to consumption. Second, an aggressive domestic savings effort is called for: from the outset of a debt cycle, the marginal savings rate must be kept at a level that is much higher than the country's average savings rate and also considerably greater than the investment rate. Third, the investment must be efficient. Fourth, the country must aggressively invest in tradable goods in order to be able to create a trade surplus large enough... so as to service the debt. Fifth, creditors must be willing to provide stable and predictable flows of finance on reasonable terms." They go on to add: "These conditions may not all be complied with in practice. Countries may experience an ongoing substitution of domestic savings by foreign savings; investments may not always be efficient or channelled sufficiently into tradable goods, and creditor behavior may differ from the desired pattern" (Ffrench-Davis and Griffith-Jones, 1995, p.228).

In general, 'main stream' macroeconomic discussions on these issues normally proceed on the basis of aggregate production and investment functions and of micro behaviour expressed by a single 'representative' firm ${ }^{7}$ A bi-directional relationship between micro and macroeconomic variables should be explicitly acknowledged. Furthermore, from our own perspective, the complexity and heterogeneity of the organizational and technological patterns of each sector-and, firm- needs to be taken into account if we are rightly to understand the idiosyncratic pattern of adaptation of each country to a change in the regulatory and incentive regimes. (Nelson and Winter 1982, Dosi 1997, Dosi, Freeman, Nelson and Soete 1988).

Different rates of accumulated learning from the part of firms and differences in the way the 'sources' of technical change are affected in different activities by structural reforms will influence

\footnotetext{
${ }^{7}$ In other words, structural heterogeneity in the patter of adjustment is very seldom admitted. A notable exception in this respect can be found in a recent book by Ffrench-Davis (2000) who explicitly states, in relation to the functioning of markets, that : 'Factor heterogeneity or market segmentation is one of the most tipical features of developing countries. This, naturally, affect the transparency and flow of information.'
} 
the capability of firms and industries to survive to the change in the global incentive regime and thus affect the structure and behaviour of the emerging 'new' production structure. On the other hand, the success of the adjustment process also seems to depend upon productivity growth and international competitiveness, both of which are strongly dependent upon domestically accumulated technological capabilities. In other words, the adjustment path will not only depend on how macro variables operate during the transition but also-and crucially - on how firms and industries adapt themselves to the new incentive regime and respond in terms of productivity growth and international competitiveness. Firms are crucial (but not exclusive) repositories of knowledge and their routines and growth strategies are central to the long-term sustainability of the growth process. This idea is central to the characterisation of growth as proposed in Nelson and Winter (1982). According to them, 'competence' is a set of differentiated technological skills, assets, and organisational routines and capacities that provide the basis for the firm's ability to 'forge ahead' and grow. Such abilities seem to us to be central to the structural adjustment process we are hereby examining.

The length and depth of the contraction phase following the application of a structural reform programme depend to a large extent on how the various economic activities react to the change in 'macro' prices and regulatory institutions, and on how this affects aggregate productivity growth and international competitiveness. There is no reason whatsoever to believe that firms and sectors will behave similarly neither can we proceed on the basis of the notion of a 'representative firm' situation which would allow us easily to predict what the consequences of the adjustment process are likely to be. Firms and sectors differ not just because they produce different goods and services, but also because they respond differently to changes in institutions and technological opportunities conditioning their long-term growth path. Cumulative experience and "path dependency' certainly influence their current status (Cimoli and Della Giusta 2000).

Returning now to Figure 1 we notice that if the economy remains trapped at $\mathrm{B}$ the local economic authorities will need to introduce changes in the macropolicy regime if they want to revert the situation to one of a higher growth rate capable of reducing unemployment. An uncertain macroeconomic environment accounts for a low rate of technical progress and innovation and this, in turn, creates new difficulties to substain the exchange rate and the external balance of the economy. Thus, a new pattern of production specialization which negatively affects domestic value added, innovation and productivity growth can result in long term pressure on the exchange rate, indicating that the micro is not solely a neutral sounding board of what is happening at the macro. Rather, it acts as a dynamic force of its own, reinforcing critical aspects of the aggregate macro-tomicro adjustment process.

Thus, in both cases, - that is, after a successful passage from D to E, or after 'stumbling back' and returning to B, before the economy can be finally put into a steady course to E- it is in the third phase of the macroeconomic adjustment process that the country should be imagined as proceeding along a new long term growth path, with savings and investment growing significantly over time. The demand curve moves outwards, prompting proactive investment behaviour from the part of firms. This should lead to the technological modernization of pre-existing production facilities as well as to the accumulation and upgrading of technological capabilities. 
If we now consider the situation at the sectoral and micro level we can intuitively perceive that a new market structure and technological 'regime' emerge during the adjustment process. Many firms are forced to exit the market. New entry takes place, particularly during Phase 3 of the adjustment process. Firms that have managed to survive the crisis now share the market with imports, which capture a sizeable fraction of domestic demand. As a result of many SMEs leaving the market during the adjustment process the average size of plant as well as labour productivity both increases during the transition to a new global incentive regime. The industry can be thought as moving into a new competitive and technological regime that strongly differs from the previously existing one. Lets examine some of the more salient features of such 'regime'. 



\section{A new pattern of production specialization}

We have argued above that although macroeconomic forces are obviously important as determinants of microeconomic behaviour, also meso and micro variables play a crucial role explaining why, under the same set of macro circumstances, some industries and firms manage to 'forge ahead' while others 'lay behind' in the adaptation to a new global incentive regime. Sectors behave differently not just on account of the fact that they respond differently to changes in 'macro' prices but also because they live under different institutional, technological and competitive 'regimes'. Property right on natural resources, patents, and other such institutions affect differently different sectors of economic activity.

Considering the specificity of the present Latin American transition to a more open and de-regulated economic environment we notice that the sectors that have suffered the most from recent trade liberalization and market deregulation efforts are those producing knowledge-intensive goods and services, on the one hand, and those producing labour intensive non-durable consumer goods like footwear, clothing or furniture, on the other (Katz 2000). The first ones have found it difficult to compete with suppliers form more developed 
industrial countries producing more sophisticated products 'embodying' recent changes in the world's technological frontier in fields such as informatics, genetic, biotechnology and the like. The second ones have not been able to face the competition of cheaper Chinese or Vietamese shoes, garments or simple capital goods. SMEs figure prominently in most of the 'lagging behind' activities, while transnational corporations and domestic conglomerates have done better in their adaptation to the new rules of the game. On the other hand, the activities that have managed to 'forge ahead' during the last two decades are: a) non tradable sectors producing services, such as telecommunication,energy or banking ${ }^{8}$; b) natural resource processing industries producing industrial 'commodities' (such as pulp and paper, iron and steel, vegetable oil, etc), c) 'in-bond' assembly industries producing electronic equipment, TV and video sets and garments, and finally, d) the vehicle industry, which received special policy treatment during the course of the trade liberalization episode.

As a result of the above two quite different patterns of production specialization have emerged in Latin America in recent years (Katz 2000 and Cimoli 2000). The first, which is mostly to be found in Argentina, Brazil and Chile, shows a strong shift towards natural resourceprocessing industries producing 'commodities' for highly competitive world markets. These industries are very capital intensive in nature and they generate very little new employment, if any.

A different pattern of production specialization can be found in the case of Mexico and some of the scalar Central American countries, which have specialized in assembly, or maquilatype, industries catering mostly for the United States markets. These sectors are intensive users of cheap low skilled labour. Mexico's maquiladoras have generated a dramatically large number of new jobs in the 1990s. They use state-of-the-art, just-in-time technologies, with a unit import content as high as $98 \%$ of the total value of shipments. These firms employ total quality techniques, Kanban and sophisticated production logistics, most of which is generated outside of Mexico. They pay a small fraction of the wages prevailing in more developed countries (no more than 10\%), and they are almost exclusively geared to exports (Capdevielle, Cimoli and Dutrenit 1997).

Table 1 presents the empirical evidence supporting the above argument. It shows how the pattern of production specialisation has changed in Argentina, Brazil, Chile, Colombia and Mexico over the last two decades. We notice a clear shift in favour of natural resource-based industries in the Souther Cone of the region, and towards the maquila sector (including the vehicle industry) in Mexico. More specifically, the natural resource-based industries classified by the ISIC as 341, 351, 354, 355, 356, 371 and 372 gained ground in Argentina, Brazil, Chile and Colombia. In Mexico, the automotive sector doubled in relative participation in the country's total manufacturing output.

Pari pasu with the above, labour-intensive industries catering for the domestic market lost ground throughout the period in each of the countries under examination.

\footnotetext{
${ }^{8}$ Many of these activities are presently turning into 'tradables' under the new globalization trends.
} 
Table 1

CHANGES IN THE RELATIVE WEIGHT OF INDUSTRIAL SECTORS IN TOTAL MANUFACTURING OUTPUT (1970-1996)

(Percentages)

\begin{tabular}{l|c|c|c|c|c|c|c|c|c|c}
\hline & \multicolumn{2}{|c|}{ Argentina } & \multicolumn{2}{|c|}{ Brazil } & \multicolumn{2}{c|}{ Chile } & \multicolumn{2}{c|}{ Colombia } & \multicolumn{2}{c}{ Mexico } \\
\hline Sectors & $\mathbf{1 9 7 0}$ & $\mathbf{1 9 9 6}$ & $\mathbf{1 9 7 0}$ & $\mathbf{1 9 9 6}$ & $\mathbf{1 9 7 0}$ & $\mathbf{1 9 9 6}$ & $\mathbf{1 9 7 0}$ & $\mathbf{1 9 9 6}$ & $\mathbf{1 9 7 0}$ & $\mathbf{1 9 9 6}$ \\
I & 15.6 & 13.1 & 18.8 & 22.8 & 14.9 & 10.2 & 10.7 & 10.5 & 13.3 & 13.9 \\
II & 9.9 & 12.1 & 9.9 & 8.7 & 7.7 & 2.0 & 2.9 & 6.5 & 5.5 & 10.8 \\
III+IV & 36.2 & 45.7 & 35.8 & 42.4 & 43.2 & 56.2 & 45.7 & 51.2 & 46.8 & 46.5 \\
V & 38.2 & 29.0 & 35.5 & 26.1 & 34.2 & 31.6 & 40.7 & 31.8 & 34.4 & 28.8 \\
\hline
\end{tabular}

Source: Author's compilation, on the basis of the Programme for the Analysis of Industrial Dynamics (PADI), Economic Commission for Latin America and the Caribbean (ECLAC), Santiago, Chile.

Sector I: Metal-working industry, excluding automobiles (groups 381, 382, 383 and 385 of the International Standard Industrial Classification, or ISIC).

Sector II: Transport equipment (ISIC group 384).

Sector III + sector IV: Foodstuffs, beverages and tobacco (ISIC groups 311, 313 and 314) and natural resourceprocessing industries (ISIC groups 341, 351, 354, 355, 356, 371 and 372).

Sector V: Labour-intensive traditional industries (ISIC groups 321, 322, 323, 324, 331, 332, 342, 352, 361, 362,369 and 390).

How does the above change in the pattern of production specialisation reflect in the relative productivity gap Latin American manufacturing activities exhibit vis a vis the international productivity frontier? Taking the evolution of labour productivity in the US industrial sector as a 'proxy' for the outward movement of the international frontier we notice that the - highly protected - automobile industry as well as natural resource processing activities were the ones that did relatively better vis a vis the international scenario. This clearly confirms the fact that in the production of tradable goods and services it is these activities that have managed to 'forge ahead' during the course of recent structural reforms. It is in these activities, as well as in non-tradable sectors, that we can talk about Latin American countries partially 'closing up' the relative productivity gap with more mature industrial economies. Contrariwise, R\&D and engineering intensive activities - such as those producing pharmaceutical raw materials and capital goods - as well as unskilled labor intensive industries, producing shoes, garments or furniture for the domestic markets, appear to be the ones that have done worse, rapidly loosing ground vis a vis the evolving international frontier (Katz and Stumpo 2000). 
RELATIVE LABOR PRODUCTIVITY GAP VIS A VIS US INDUSTRIES ACCORDING TO FACTOR INTENSITY UTILIZATION IN THE PRODUCTION FUNCTION.

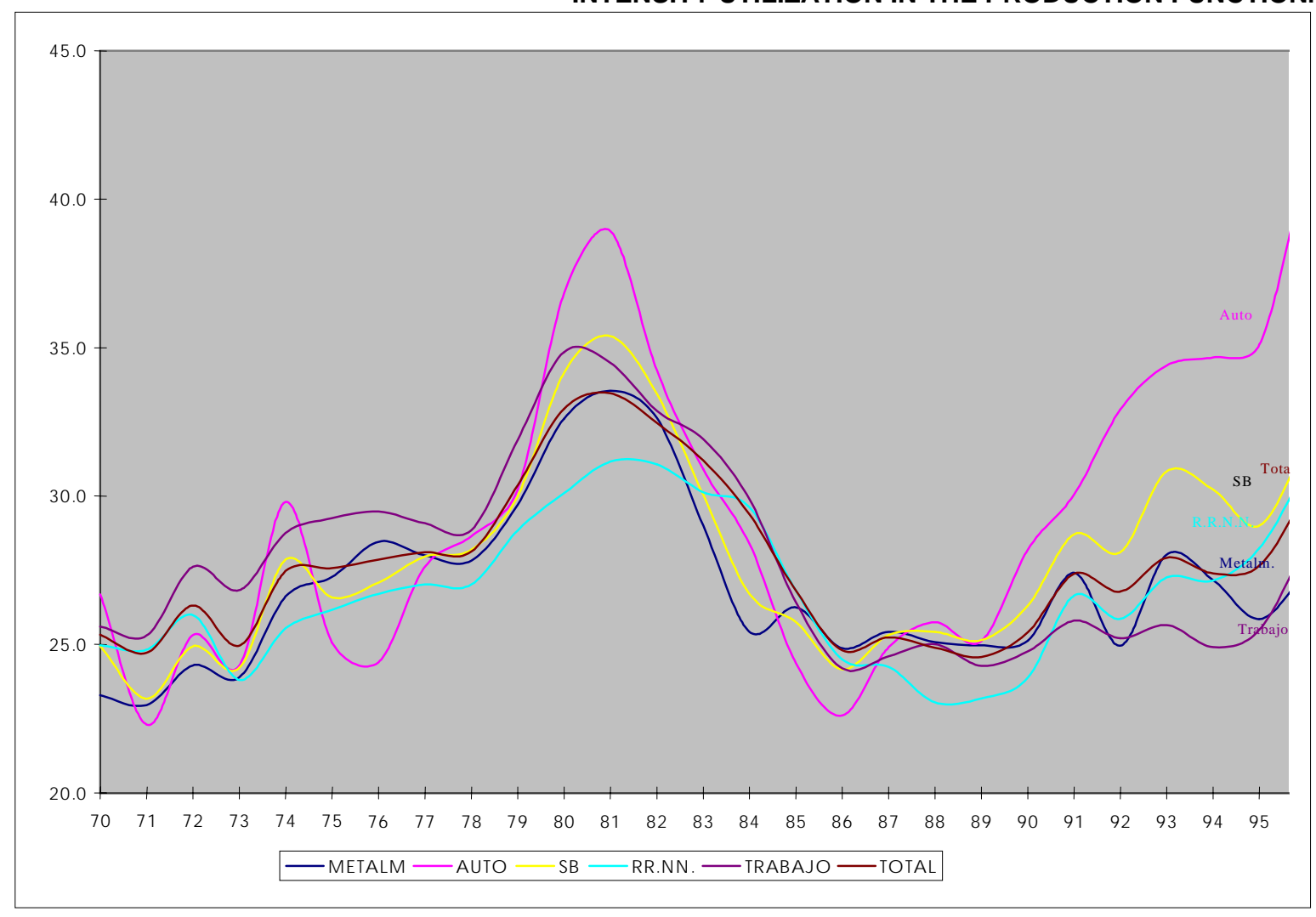

Washington-consensus authors have a priori argued that trade liberalisation and market deregulation efforts were automatically to induce a dynamic shift of the Latin American production structure. In fact, within this general picture, one can observe that most Latin American economies have followed the expected path, changing their specialization on the basis of their factors endowments: natural resources and labour. The Southern Cone countries (such as Argentina, Brazil, Chile and Uruguay) have intensified their specialization towards natural resources and standardized commodities. These are now highly capital intensive industries. Conversely, countries such as Mexico and the Central American nations have moved into assembly activities based on the cheap labour. Such specialization pattern encapsulated an intra-industry transformation that affect the sustainability of the macro adjustment process. 


\section{Structural reforms and intra- industry restructuring process}

When macroeconomic stabilization efforts and structural reforms come together (as was the case in several countries in the region in the 1970s and early 1980s), firms had simultaneously to cope with the contraction of the domestic market, on the one hand, and the massive arrival of imports (due to tariff reduction ), on the other.

In the new competitive 'regime' imports managed to capture a significant fraction of the market, and only some of the existing firms could survive by lowering their production costs and specialising in particular market 'niches'. Many firms-mostly SMEs - were forced to exit the market during the adjustment process. What is the empirical evidence concerning this topic?

Mizala reports that some 7,000 Chilean firms closed down in the mid-1970s and early 1980s, most of them medium sized. For different reasons, small and large firms found it relatively easier to survive the drastic change in the macroeconomic policy regime that was implemented in Chile following the military coup of 1973 (Mizala, 1992). In Argentina, an estimated 15,000 industrial firms 
exited the market during the trade liberalization process implemented in the late 1970s. In both cases, the exodus was particularly intense in labour-intensive industries, such as those producing garments, footwear and textiles, as well as in metalworking industries producing capital goods and machine tools. (Katz, 1986).

Many sectoral studies illustrate the dynamics of this process. In the Argentine steel industry, for example, half of the firms registered by the industry in the early 1970s left the market in the 1980s: the number of firms fell from 59 in 1975 to 26 in 1992 (Azpiazu and Basualdo, 1995). The Chilean footwear industry constitutes another example. The number of firms in the industry fell from 275 in 1979 to 186 in 1982 (Kassai, 2000). In the Argentine vegetable oils industry, the number of firms fell from about 70 in the 1970s to approximately 50 in the early 1990s (Obschatko, 1997). Similar trends can be seen in the Brazilian pulp and paper sector (Bercovich, 2000) and in the Chilean copper industry (Cáceres, Cárdenas and Katz, 2000). In all of these cases, intraindustry restructuring involved a process of selection among firms and a major transformation of the sector's technological and competitive regime. Business concentration increased in every case, and only a small number of firms approached international productivity standards.

As far as entry of new firms is concerned, fragmentary evidence indicates that this occurs mostly during the third stage of the macroeconomic stabilization process and normally involves production facilities of a much more modern vintage. In the case of the Argentine iron and steel industry, for example, two large-scale, Acindar S.A. and TECHINT S.A set up state-of-the-art steel mills in the 1990s. The industry was thus restructured around a new model of industrial organization in which two large domestic conglomerates gained control over the sector forcing out of the market a large number of medium size non-integrated steel mills. (Azpiazu and Basualdo, 1995). Techint S.A. now operates as a global player on the international seamless tubes markets, capturing nearly one quarter of world's sales.

The Argentine vegetable oil industry is another case at point. The restructuring of this sector was associated with the entry of a new generation of plants, which not only were bigger in size, but also incorporated a different basic process technology. The industry gradually moved towards catalytic-based production processes leaving behind 'old' more conventional production techniques. Furthermore, pari pasu with the above the industry's institutional landscape also changed dramatically. New firms entered the market, and new forms of vertical integration developed between production, transport, dock facilities and overseas shipping (Obschatko, 1996) as the State proceeded to privatize railways and docks terminals which were taken over by the oil producing companies. This clearly reflects the co-evolution of economic, technological and institutional forces underlying the growth path for this industry.

In sum, the available empirical evidence supports the idea that intra-industry restructuring processes are strongly related to the exit of firms from the market, to the entry of new plants featuring better production and organization technologies and a gradual transformation of the sector's competitive and institutional 'regime'. Such evidence confirms that the coevolution of economic, technological and institutional forces plays a major role at the sectoral level, quite independently of what macroeconomic circumstances happen to be. 
As macroeconomic stability is restored, i.e. during Phase 3 of the adjustment process, entrepreneurial 'animal spirits' revives and some firms invest in new production facilities, in new product designs, and so forth. A new balance between domestic firms and imports tends to settle with a much smaller number of local companies surviving the transition to the new competitive and technological regime. From this perspective, recent trade liberalization cum structural reforms efforts can be seen as a strong 'selection mechanism' inducing the transition to a new competitive and technological regime at the sectoral level.

The economic profession clearly lacks a good macro-to-micro theory in terms of which to study situations of this sort. Furthermore, it lacks a theory useful to explain the entry and exit of firms, which would help us to identify the reasons on account of which some firms win while others loose participation in transitions between growth paradigms as the ones, we are here examining. Much of our previous discussion is based upon empirical observations resulting from individual case studies, which show remarkable regularity across industries and countries, regardless of whether they involve the manufacturing of footwear, furniture, machine tools or clothing.

Figure 3

ENTRY AND EXIT FIRMS TO AND FROM THE MARKET

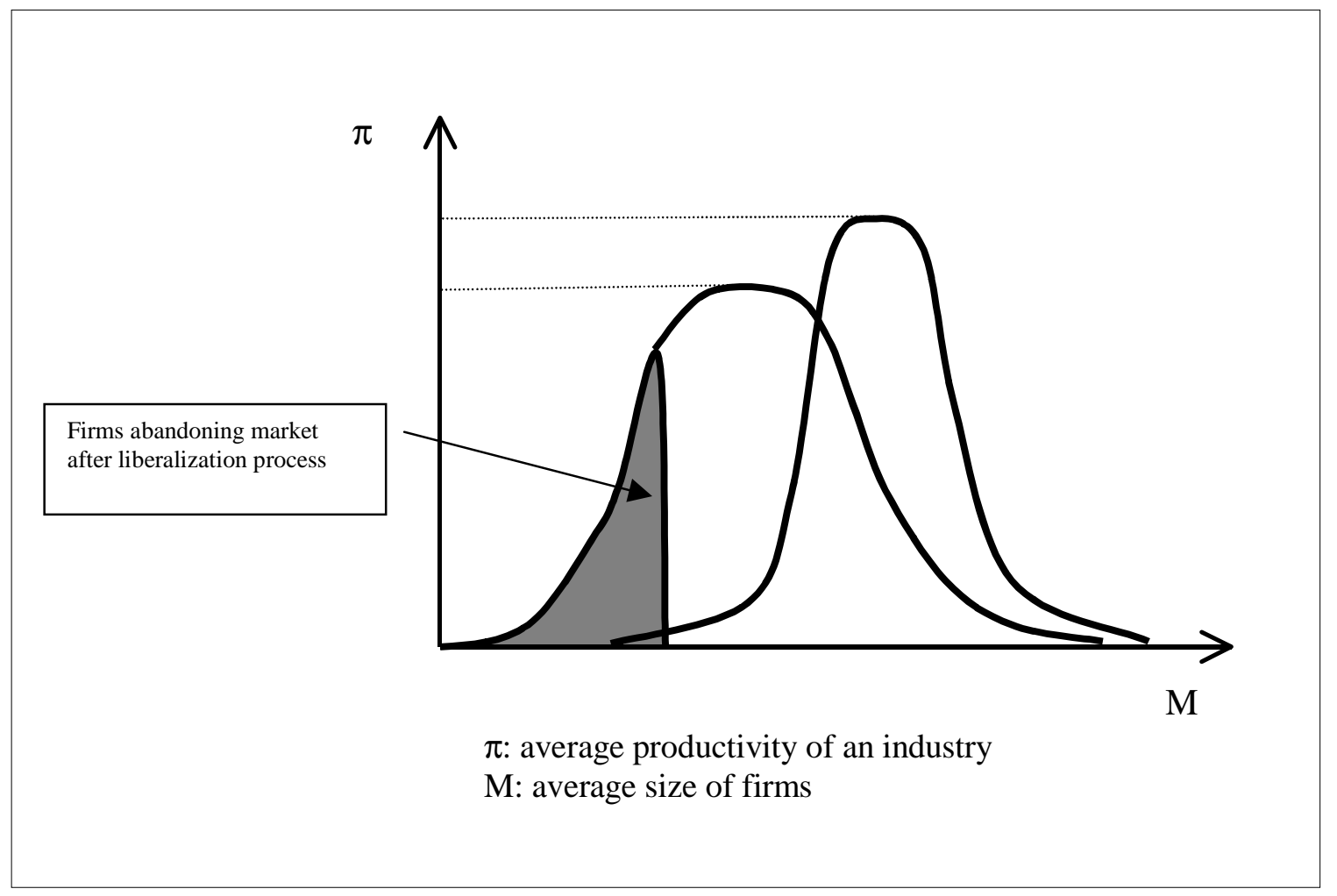

The generalized interdependencies between macro- and microeconomic processes and the joint impact of regulatory, economic and technological forces are clearly evident. Trade liberalization and market deregulation efforts carried out in the context of large market failures and asymmetric information across firms have induced a dramatic transformation of sectoral 
competitive and technological regimes. Economic concentration has increased, as has the exit of small and medium-sized family firms from almost every market (Katz 2000)). Figure 3 describe synthetically this process. Sectoral labour productivity $(\pi)$ and the average size of firms, measured by $\mathrm{M}$, increase as a result of trade liberalization and of the modernization of production processes.

Different circumstances seem to explain why some firms survive the transition towards a more competitive market environment while others do not. Some of these circumstances reflect the role of accumulated technological capabilities at the level of the firm. On the other hand, also market imperfections and information asymmetries that lead to the exclusion of certain firms from access to long term capital or technology play a significant role here winnowing across firms. Thus, it is not just firm inefficiencies and market failures that act as a 'selection mechanism', as in the neo-classical model, but also the maturity and technology accumulated in each firm that play an important part here as well. 


\section{External versus domestic 'sources' of technical progress.}

The sequence of events so far described obviously affects the way in which domestic technological capabilities and engineering skills are delayed in the economy after trade liberalization and market de-regulation efforts (Katz 2000 and Cimoli 2001). They also affect the long-term accumulation of technological capabilities. Just as old vintages of machinery and equipment are rendered obsolete by the rapid inflow of new, computer-based machines, so, too, do certain forms of human capital lose relevance in the new production organization environment. Consider, for example, the case of plant engineers who were previously employed to extend the life cycle of the available machines, in a world in which new machines were either very expensive or difficult to obtain. Trade liberalization obviously changes the rules of the game in this respect making imported machines cheaper and more easily available. Moreover, latest 'vintage' equipment is also 'better' per dollar of machine, in so far as it embodies computer-based process technologies, which are far more efficient than outmoded electromechanical production techniques. Obviously a number of engineering activities carried out in plant either to extend the life cycle of old machines or to perform technical activities which now come 'embodied' in the new pieces of equipment, are rendered unnecessary and quite frequently the engineers and technicians involved in such activities can be cut off from the payroll (Katz 2000). Similarly, complete research and development $(\mathrm{R} \& \mathrm{D})$ and project engineering departments can be 
eliminated when firms become part of world-wide integrated production systems, - as it is the case of Ford Argentina, whose story we discussed in the introductory paragraphs of this paper- and $R \& D$ and engineering efforts are transferred to headquarters.

The same is observed in the case of public firms providing telecommunications, electricity and transport services which after privatisation discontinued their domestic R\&D and engineering departments turning to their respective central offices for technology and engineering services. These changes in production organisation involve the "destruction" of human capital and domestic technological capabilities and their substitution for capital 'embodied' new technology, as well as for foreign-produced R\&D and engineering services. Some of the skills and technological capabilities rendered redundant by the new production organization arrangements can and have been successfully transferred to other areas of the economy - say, to a newly emerging and rapidly expanding software industry - but there are clear differences across nations, regions and industries in the extent to which such redeployment has actually taken place.

We now proceed with the development of a simple model describing the above set of issues. It is clear that reducing the technology gap with more mature industrial societies by importing cheaper and better machines from abroad has significant implications for the way in which engineering skills and domestic technological capabilities are employed and/or 'destroyed' during the adjustment process.

Figure 4 presents a stylized description of our case. The transformation curves at the top right hand quadrant show the various combinations of domestic $\left(\mathrm{K}_{\mathrm{D}}\right)$ and imported capital goods $\left(\mathrm{K}_{\mathrm{F}}\right)$ with which any given firm would chose to operate at different relative prices. Suppose also that the domestic capital and equipment are locally produced and repaired within the same plant. And that the imported pieces of machinery are somewhat better than those locally produced on account of the fact that they incorporate numerically-controlled production techniques, i.e. they are computer-based.

Consider now the upper left-hand side quadrant, in which we describe the relationship between capital goods and engineering services. As explained before, using more and better machines necessarily means that less engineers and maintenance technicians will be needed at the shop-floor level, i.e. that a certain fraction of the skilled personnel available in plant would be rendered unnecessary when we replace 'old' machines by new and better ones.

The schedule FF in the right hand side lower quadrant indicates how much the commercial policy is neutral or not to international relative prices. A schedule at 45-degree, as in the case depicted in figure 4, represent the case of a neutral policy where domestic and international relative prices are equals. An anti-clockwise movement would thus reflect government policy actions aiming at discouraging (or reducing) capital goods imports; conversely, one can imagine a clockwise rotation of the schedule FF if the importation of capital goods is stimulated.

In this scenario, a reduction of import tariffs will reduce the relative price of imported capital goods vis a vis the locally produced ones. Cheaper imported machines induce a movement from A to $\mathrm{B}$. In other words, the utilisation-and production- of domestic capital is reduced when the 
relative price of the foreign one is reduced. As a consequence of the substitution of the domestic capital goods, the employment of technical personal in engineering and R\&D activities is reduced. Finally, consider the schedule $\mathrm{T}$ in left-hand side lower quadrant which says that the change in relative prices induces more machines to be imported and, thereafter, less engineers and technicians to be used in plant. Thus, we can draw as solution of our model a curve that describes the relationship between changes in relative prices and imports of capital goods, on the one hand, and the substitution of imported 'embodied' know how for local engineering capabilities, on the other.

Moreover, if the newly imported machines are not only cheaper but also somewhat 'better' than the formerly employed ones it follows that for the same amount of output less equipment will be required by the firm. In this case, the movement to the left in the top right hand side quadrant represents a change toward better (and cheaper) machines; our curve moves toward the left, from $\mathrm{KF} 1$ to KF2. As a consequence of the incorporation of new foreign capital goods in local plants, both engineering and human capabilities are replaced more intensively. The schedule $\mathrm{T}$ will turn clockwise to T' indicating that with new and better machines the process of 'destruction' of local technological capabilities is intensified. If output increases and for such purpose more machines are imported the relative displacement of local engineers and technicians will be even larger.

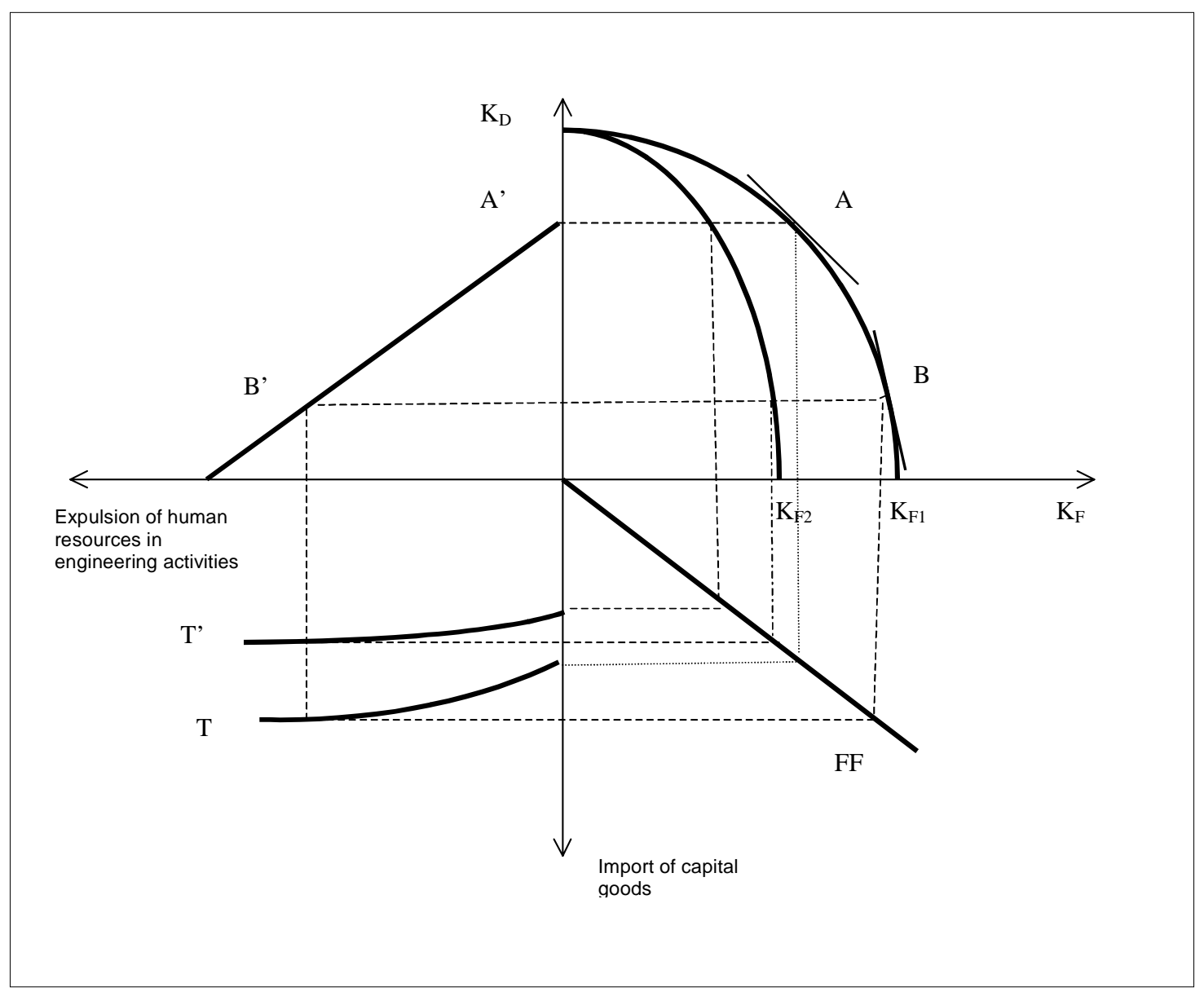


Recapitulating: we first have the impact of a change in relative prices upon the choice between purchasing domestically produced versus imported capital goods. We have here a conventional substitution effect between domestic and imported equipment. Ceteris paribus, a lower relative price of foreign capital goods vis a vis domestically-produced ones will induce an increase in imports of the former. Such first movement will render unnecessary a certain fraction of the engineers and technicians used at the shop-floor level in maintenance operations intended to extend the life cycle of 'old' machines. In an open and de-regulated world economy in which firms can easily and cheaply import new capital goods of a superior vintage the development of domestic technological capabilities is bound to confront serious difficulties. Not being the production of new technology among the local comparative advantages, local firms and industries could be expected increasingly to relay of technical change 'embodied' in new machines and 'on line'engineering services coming from abroad. Under such circumstances most knowledge production will tend to be localized outside of the developing country's production environment with a clearly deleterious impact upon the accumulation of domestic technological capabilities.

Fragmentary empirical evidence tends to support the picture so far presented. The industries and firms which have done better in recent decades have certainly been successful in deverticalizing their production organization turning to external subcontracting of intermediate parts and components and also of technology and engineering services. They have increasingly concentrated on relatively low value added activities and in assembly operations. The more 'on line' and capital-intensive new production technologies have become the less local firms have chosen to employ domestic technological capabilities as a source of supply for their technological requirements.

Some of the available engineering and technological capabilities have been successfully reallocated in other areas of the economy, where they have been absorbed in the starting up of new knowledge intensive activities, such as software production, biotechnological companies and so forth. The extent to which this has been so, however, appears strongly to depend upon micro-to macro interactions influencing the rate of investment and the rate of company start-ups. However, structural unemployment of highly qualified human resources is a common fact in most manufacturing plants, as a consequence of the fact that the new pattern of production specialisation is strongly biased against the employment of skilled human resources. 


\section{Increasing returns to scale and the technological gap}

Having so far presented a micro-to-macro stylized description of the adjustment process of the Latin American economies after recent trade liberalization and market de-regulation efforts, we now turn to another major analytical issue, which requires consideration. To what extent, in a world of increasing returns to scale in the production of knowledge, and of synergies and interdependencies between firms and other repository institutions involved in the 'production' of human capital and technology, (such as universities, public R\&D laboratories, and so forth), the conditions are given for the globalisation process to induce a dualistic world-wide pattern of production organisation in which $\mathrm{R} \& \mathrm{D}$ and engineering activities increasingly will tend to concentrate in mature industrial countries while developing economies will tend to specialize in the production of industrial 'commodities' with low domestic engineering content, as well as in 'maquila'-type assembly operations?

We have previously argued that Internationally Integrated Production Systems (SIPI) have significantly gained in relative participation in GDP during the course of the past decade throughout Latin America. We have also seen that in many cases this has involved the transferring abroad of many $R \& D$ and engineering activities previously carried out 'in house' by LDCs manufacturing plants. The 
local operation has turned more into the nature of an assembly activity, based on imported parts and components as well as on externally supplied technological and engineering services. This mechanism is likely to induce an increasing isolation of peripheral countries from the world of technology generation. We now present a simple model describing in a stylized fashion our views on this topic (Cimoli (2001).

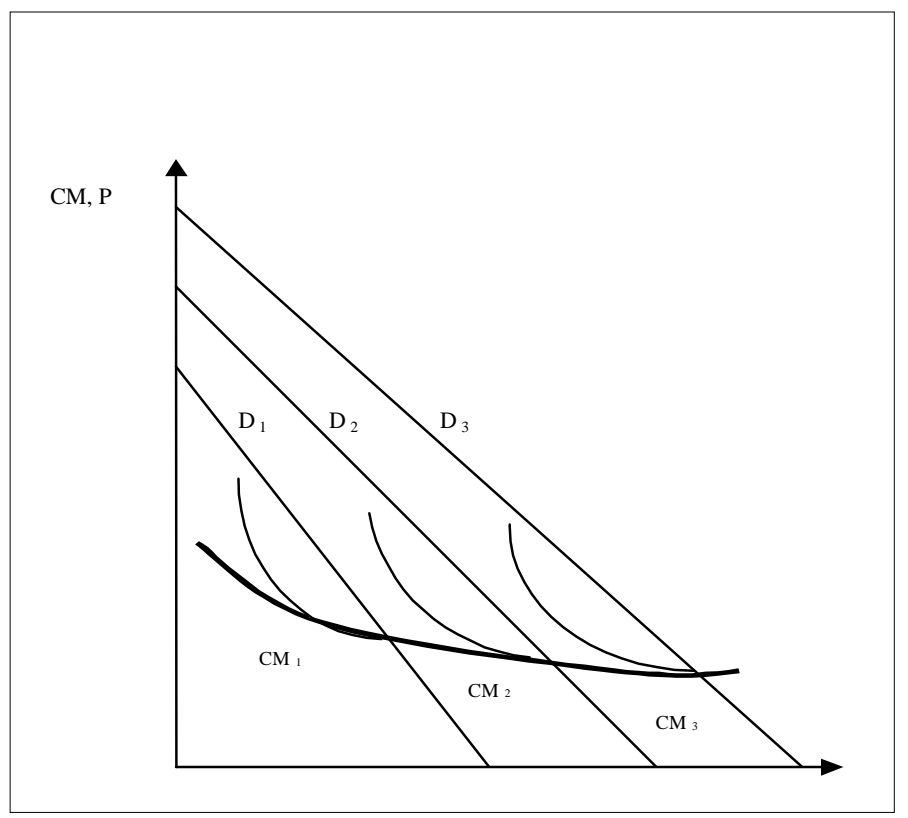

Figure 6 COMPETING FIRMS UNDER INCREASING RETURNS

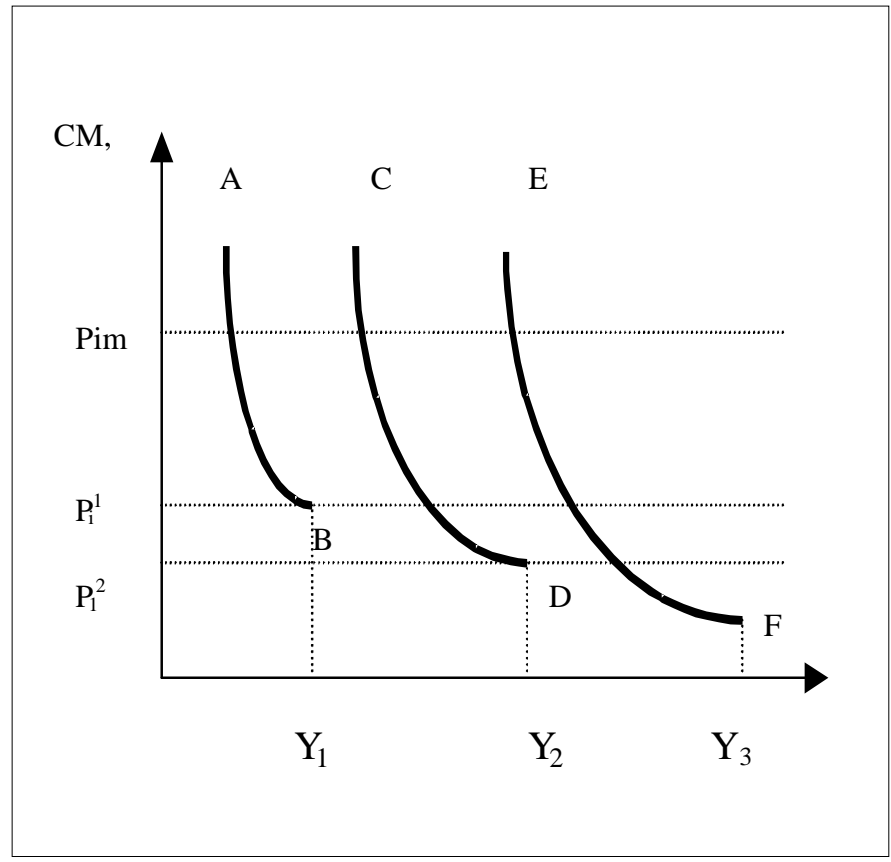


Figure 7 SELF-REINFORCING MECHANISMS

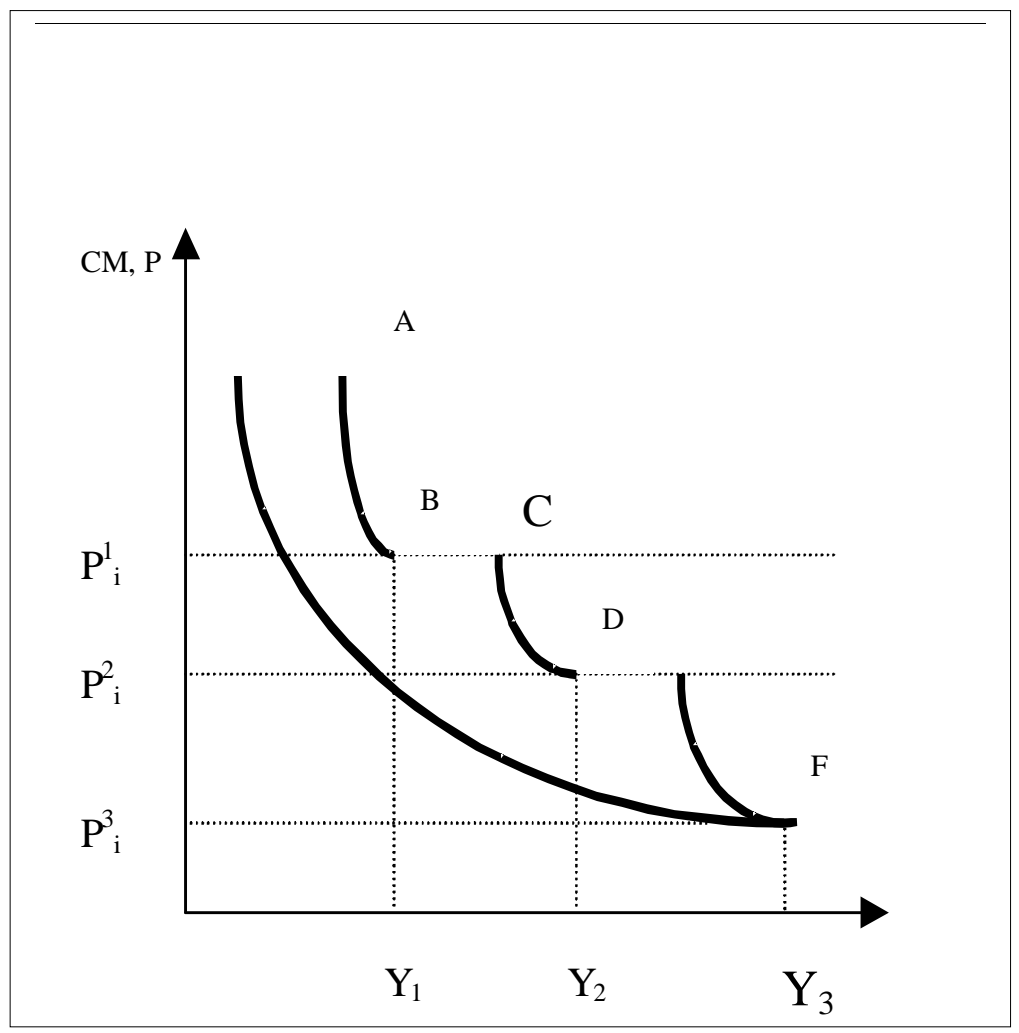

Figure 8 MODERNIZATION OF LOCAL FIRMS

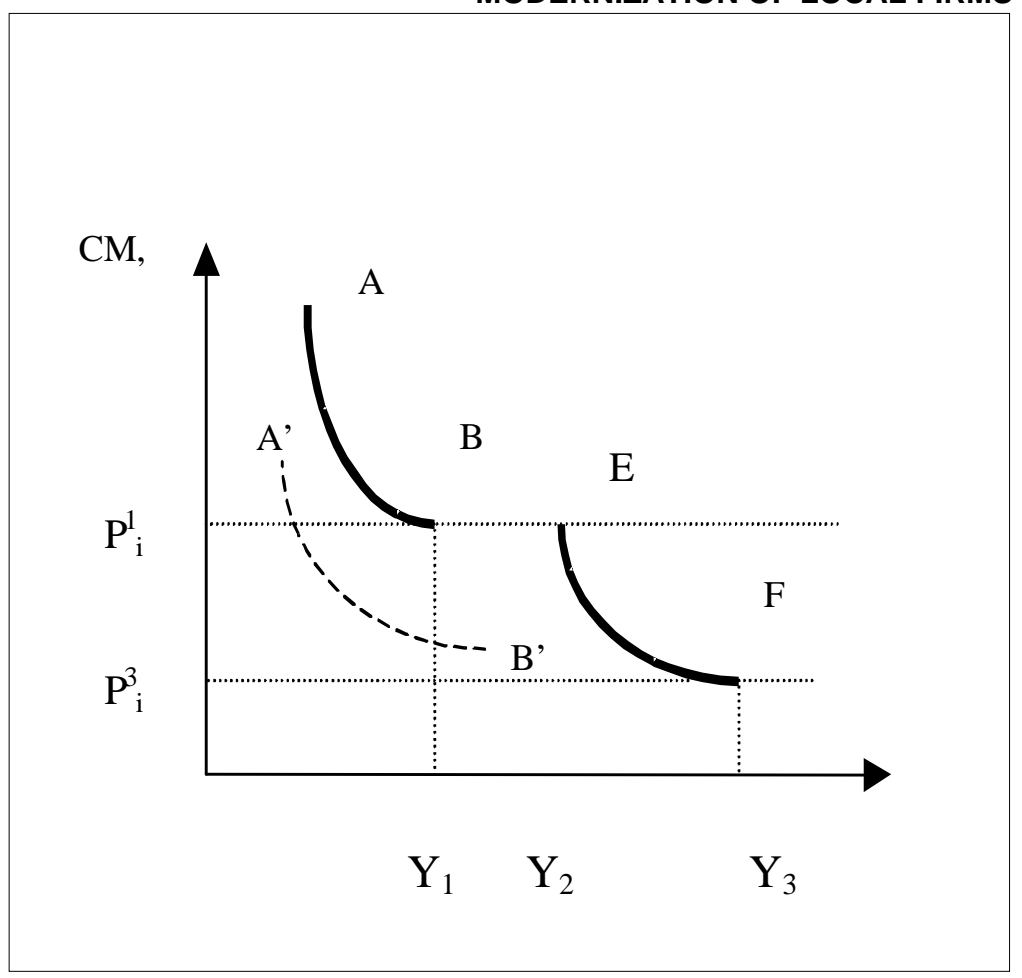


Suppose first that we are dealing with an homogenous product and that as a result of a generalised process of liberalization a given multinational enterprise finds itself operating in a world market place in which the demand for its product moves outward, as from D1 to D3 in Figure 5. The firm attains lower long term average production costs, as shown in the figure, as a consequence of specialisation of the actors members of the SIPI and increasing returns to scale for the production as a whole9. As the liberalization to trade is diffused in most countries a number of reinforcing mechanisms tend to operate reflecting not just conventional economies of scale to the firm, but also institutional synergies and sunk-cost which induce the reallocation of knowledge intensive activities toward the central premises of the corporation which is were the firm stands to capture significant externalities from the more mature home-base technological and human capital environment (Chesnais (1995), Freeman and Hagedoorn (1995)).

Such process has significant consequences for the technological 'regime' eventually to develop in peripheral countries. With the help of the figure 6, we can now examine possible alternative outcomes.

Consider first a case in which we have three firms of different size, whose average costs functions we represent by schedules $\mathrm{AB}, \mathrm{CD}$ and $\mathrm{EF}$ producing a given homogenous product, using different production processes. Their scale of production are represent by $\mathrm{Y}_{1}, \mathrm{Y}_{2}$ and $\mathrm{Y}_{3}$, respectively. Assume now that $\mathrm{EF}$ is the cost schedule of a foreign-controlled global production network. Initially the country has an ad valorem tariff, which sets the price a $\mathrm{P}_{\mathrm{im}}$. For all prices below $\mathrm{P}_{\text {im }}$, local consumers acquire the local version of the product. In this case the local firms take the whole of the domestic market, with the firm with the $\mathrm{AB}$ cost curve predominating. As structural reform efforts are undertaken and import tariffs are lowered domestic firms have to face competition from foreign firms. The firm with an EF curve becomes dominant. The lower costs attained by the foreign company could induce it to set the price below the variable costs of the two local firms, forcing them out of the market. Market structure changes to that of a large dominant company and a few smaller competitors (figure 7). It could also choose to allow domestic companies to survive, setting up a high price and capturing high unit gross margins on sales (figure 8). In other words, the globalization process can induce more output and lower prices to prevail in the market or a somewhat smaller level of production and high unit gross margins being captured by the foreign company entering the market.

Figure 7 shows that trade liberalization acts as a strong force inducing market concentration and a transition toward monopolistic market structures. Such tendency is reinforced by the fact that the foreign company controlling the market can derive important synergies and externalities from its own home-based institutions as well as from its accumulated technological capabilities. In effect, foreign 'sources' of technical change and productivity growth tend to acquire prominence, as the dominant firm outsources its requirements of new capital goods as well as of R\&D and engineering services in its home country. In this sense the globalization process clearly re-inforces the prevailing technological gap between both countries.

\footnotetext{
${ }^{9}$ This assumption is based on the idea that scale economics in production is the cause of barriers to entry; similarly, to the structural model developed by Bain (1957), Sylos Labini (1962) and Dosi (1984).
} 
These evolutionary characteristics of market structure and of the technological 'regime' are seen in a complementary perspective as responsible for the occurrence of what has been called "lock-in" by historical events and "self reinforcing process" (Arthur 1989, David 1989, Dosi 1999). Liberalization and globalization of markets in a context of competing firms under increasing returns to scale mechanisms can eventually reinforce the technology gap between nations, if the 'destruction' of local capabilities is not compensated by technology transfers from the part of the globalised firms. Several recent studies suggest that this might happen; however, it is not the only possible outcome.

The take over and technological overhaul of the local company under the guidance of the newly entering multinational enterprise can be an alternative. We should notice that under certain circumstances it might be more convenient for the large multinational firm to enter the market through a take over of a local firm but profiting from the fact that such firm might have high domestic reputation, well established trade marks and so forth.

Mergers and acquisitions have proceeded at a dramatic pace in recent years throughout Latin America. From the point of view of the model we can think that the foreign company sets the price at $\mathrm{P}_{\mathrm{i}}{ }^{1}$ and allows the coexistence of the local production facilities and of its own parallel sales, under different trademarks. This is frequently the case to be observed in Mercosur or NAFTA, where local subsidiaries of multinational corporations have taken over the larger and better domestic companies and have moved into the co-marketing of competing products under different trade marks. In many of these cases the acquired company undergoes a deep process of technological modernization. Figure 8, describes such a situation by showing a downward shift in the cost schedule AB. The new schedule A'B' can be attained after a major upgrading of the company's product and or process technologies under the supervision of the large multinational firm. The same figure could also be used to describe the case of 'independent modernization' of a local firm that decides to go its own way, specializing in specific market 'niches'. During the import substitution period, many local firms developed economies to scale and 'in house' technological capabilities that enabled them to attempt such an independent course of action after recent structural reforms. It should be noticed, however, that they frequently remain as prey of large international companies that could take over if their strategy proves to be successful. 



\section{A final overview}

Structural reforms have been implemented by Latin American countries under the expectation that after a short period of adjustment to a new macroeconomic and regulatory regime the countries in the region were to return to a stable long-term full employment growth path. Such expectation emerged from conventional neo-classical thinking that a priori takes for granted that markets operate efficiently, that firms have all the relevant information they need and act as rational profit maximisers and that factor markets behave adequately without any need for government intervention. Trade liberalisation and the de-regulation and privatisation of economic activities where deemed to be necessary and sufficient conditions for the invisible hand' to play an optimal resource reallocation job conducting the economy to a new equilibrium growth path closer to each country's long term comparative advantages.

After twenty years of policy implementation along the above lines we have to accept that Latin American economies have gone in the expected direction with regards the specialization pattern. At the macro level they are certainly more stable than in the past, and they are also more open to trade. However, this sectoral specialization by itself does not guarantee a sustainable growth pattern in the long term. In fact, from the point of view of their achievement as far as economic growth and productivity improvement is concerned, they have attained little so far. The same is true in relation to equity in the distribution of the benefits of technological modernization. 
Structural reforms have changed the pattern of production specialisation and of insertion of the countries in the region into the world's market place. Two 'dominant' situations can be identified: Southern Cone countries have specialised in natural resource processing industries while Mexico and some of the small Central American economies have done so in assembly manufacturing activities - 'maquiladoras' - basically catering for US markets.

In both models micro-to-macro interactions and a Schumpeterian 'creative/destruction' process played a paramount role. We identify here three phases in the adjustment process to a new global incentive 'regime'. Phase one is predominantly contractive while Phase three is expansionary, and obtains when macroeconomic stability is regained and macro turbulence and uncertainty are reduced. Entry and exit of firms appear as a crucial component of the adjustment process, and they take place in a context of market imperfections and asymmetric information among firms. Trade liberalisation has significantly lowered the price of imported capital goods inducing their substitution for locally produced machinery and equipment. Moreover, such process is shown to be associated to a lower utilisation of highly trained domestic human resources and to the contraction of domestically performed R\&D activities. Structural unemployment of qualified human resources is not an uncommon consequence of the economic reforms.

Furthermore, in a world of increasing returns to scale to the production of knowledge, and of externalities between firms and other repository institutions involved in the process of technology generation, the conditions are given for the globalisation of economic activities to induce a dualistic world-wide pattern of production organisation in which $R \& D$ and engineering efforts are increasingly carried out by mature industrial countries while developing economies tend to specialise in the production of industrial 'commodities' and 'in-bond' assembly industries . 


\section{Bibliography}

Arthur, B. (1989), "Competing Technologies, Increasing Returns and Lock-In by Historical Events", Economic Journal, Vol.99, No.1.

Asimakopulos A. (1977), "Profits and Investment: A Kaleckian Approach" in G.C. Harcourt (ed.), The Microeconomic Foundations of Macroeconomic, London: Macmillan, 328-42

Azpiazu, Daniel y Eduardo Basualdo (1995), "La internalización reconsiderada: el caso de Siderar", Buenos Aires, Facultad Latinoamericana de Ciencias Sociales (FLACSO), inédito.

Bain J. (1957), Barriers to New Competition: Their Character and Consequences in Manufacturing Industries, Cambridge, Massachusetts, Harvard University Press.

Bercovich, Néstor (2000), "Evolución y situación actual del complejo forestal en Argentina", documento de trabajo. Proyecto CEPAL/IDRC "Reestructuración industrial, innovación y competitividad internacional en América Latina (Fase II)".

Bercovich, Néstor y Jorge Katz (comps.) (1997), Reestructuración industrial y apertura económica: La industria de celulosa y papel de Argentina, Brasil y Chile en los años 90, Buenos Aires, Alianza Editorial.

Breschi, S. and Malerba F. (1997), "Sectoral Innovation Systems: Technological Regimes, Shumpeterian Dynamics and Spacial Boundaries" in Edquist, C. (ed) (1997), Systems of Innovation, Pinter, London and Washington

Cáceres, Jaime, Kattia Cárdenas y Jorge Katz (2000), "Instituciones y tecnología en el desarrollo evolutivo de la industria minera chilena", serie Reformas económicas, $N^{\circ} 53$ (LC/L.1349), Santiago de Chile, Comisión Económica para América Latina y el Caribe (CEPAL).

Capdevielle, M. Cimoli, M. and Dutrenit, G. (1997) "Specialisation and Technology in México: a Virtual Pattern of Specialisation", wp. IR 97016, IIASA. 
Chesnais F. (1995) "Some Relationships Between Foreign Direct Investment, Technology, trade and Competitiveness", in Hageddoorn J.(ed) (1995) Technical Change and the World Economy, Edward Elgar, London.

Cimoli M. (2001), "Networks, Market Structures And Economic Shocks, The structural changes of Innovation Systems in Latin America", Paper presented at the seminar on The Other Canon in Economics, Oslo, August, 2000; and , the seminar on "Redes productivas e institucionales en America Latina, Buenos Aires, 9-12 April, 2001.

-(ed.) (2000), Developing Innovation Systems: Mexico in the Global Context, forthcoming in the Pinter Series: Science, Technology and International Political Economy, London and New York.

Cimoli, M. and M. Della Giusta (2000), "The Nature of Technological Change and its Main Implications on National and Local Systems of Innovation", in P. Batten, D. Martellato (eds), Innovation and Regional Development, Kluwer Academic, Boston/Dordrecht/London.

David, P.A. (1989), "Path-Dependence: Putting the Past into the Future of Economics", Discussion Paper, Stanford University, Stanford.

Dosi, G. (1984), Technical Change and Industrial Transformation, MacMillan: London and New York.

-(1997), "Opportunities, incentives and the collective patterns of technological change", Economic Journal, 107, September, 1530-1547,

Dosi, G., C. Freeman, R. Nelson and L. Soete (1988), Technical Change and Economic Theory, Pinter, London.

Ffrench-Davis, R. y S. Griffith-Jones (comps.) (1995), Las nuevas corrientes financieras hacia América Latina: fuentes, efectos y políticas, México, D.F., Fondo de Cultura Económica.

Ffrench-Davis, R. (2000), Reforming the reforms in Latin America. St.Anthony Series, Oxford, 2000. First published by MacMillan Press, Great Britain, 2000.

Freeman, C. and Hagedoorn J. (1995) "Convergence and Divergence in the Internalization, in Hageddoorn J. (ed.)n (1995) Technical Change and the World Economy, Edward Elgar, London.

Kalecki M. (1990), “The Essence of the Business Upswing”, in J. Osiatyński (ed.), Collected Works of Michal Kalecki Volume I: Capitalism: Business Cycles and Full Employment, Oxford: Clarendon Press, 188-94, 487-9.

Kassai, L. (2000), "El sector cuero, calzado y afines en Chile un "cluster" tradicionalmente incipiente", Proyecto CEPAL/IDRC "Reestructuración industrial, innovación y competitividad internacional en América Latina (Fase II)".

Katz J. (1986), Desarrollo y crisis de la capacidad tecnológica latinoamericana: el caso de la industria metalmecánica, Buenos Aires, Comisión Económica para América Latina y el Caribe (CEPAL).

-(2000), Reformas estructurales, productividad y Conducta Tecnologica, Fondo de Cultura YCEPAL, Santiago (English edition: Structural Reforms, Productivity and Technological Change in Latin America, ECLAC, Santiago, Chile)

-(1987), Technology Generation in Latin American Manufacturing Industries: Theory and Case-Studies Concerning its Nature, Magnitude and Consequences, Londres, The Macmillan Press.

Katz, J and G. Stumpo (2000), Regimenes Competitivos Sectoriales, Productividad Y Competitividad Internacional, paper presented at the ECLAC/BID seminar Mach, Santiago.

Kriesler P. (1988), "Kalecki’s Pricing Theory Revisited", Journal of Post Keynesian Economics, 11 (1), Fall, 108-30.

Lavoie M. (1977), “ Real Wages, Employment Structure, and the Aggregate Demand Curve in a Kaleckian Short-Run Model”, Journal of Post Keynesian Economics, 19 (2), Winter, 275-88.

Malerba, F. and Orsenigo, L. (1997), “Technological Regimes and Sectoral Patterns of Innovative Activities", Industrial and Corporate Change, Vol.6, N.1, pp. 83-118.

Mizala, A. (1992), "Las reformas económicas de los años setenta y la industria manufacturera chilena", Colección estudios CIEPLAN, $\mathrm{N}^{\mathrm{o}} 35$, Santiago de Chile.

Moguillansky, G. (1999), La inversion en Chile: el fin de un ciclo de expansión?, ECLAC/Fondo de Cultura, Santiago, Chile.

Moguillansky, G. y R. Bielchowsky (2000), Inversión y reformas económicas en América Latina, Santiago de Chile, Comisión Económica para América Latina y el Caribe (CEPAL)/Fondo de Cultura Económica, por aparecer.

Nelson, R. (1995), "Resent Evolutionary theorizing about economic change", Journal of Economic Literature, 33, pp. pp.48-90. 
- (1996), The Concept of Institution as an Attractor, Snare and Chalange", IIASA, mimeo.

- (1997), "How new is new growth theory?", Challenge, octubre

Nelson, R.R. and Winter, S.G. (1982), An Evolutionary Theory of Economic Change, Cambridge, Mass.: Harvard University Press.

.Obschatko, Edith (1997), "Articulación productiva a partir de los recursos naturales: el caso del complejo oleaginoso argentino", Documento de trabajo, No 74 (LC/BUE/L.157 ), Buenos Aires, Comisión Económica para América Latina y el Caribe (CEPAL).

Sylos Labini P. (1962), Oligopoly and Technical progress, Cambridge, Mass. Harvard Universitity Press

Winter, S. (1984), "Shumpeterian Competition under alternative Technological Regimes", Journal of Economic 



\section{E P A L Serie}

\section{E C ᄂ A A $ᄃ$ C desarrollo productivo}

\section{Números publicados}

50 El impacto de las transnacionales en la reestructuración industrial en México. Examen de las industrias de autopartes y del televisor, Jorge Carrillo, Michael Mortimore y Jorge Alonso Estrada, Red de inversiones y estrategias empresariales, (LC/G.1994), 1998. www

51 Perú: un CANálisis de su competitividad internacional, José Luis Bonifaz y Michael Mortimore, Red de inversiones y estrategias empresariales, (LC/G.2028), 1998. www

52 National Agricultural Research Systems in Latin America and the Caribbean: Changes and Challenges, César Morales, Agricultural and Rural Development, (LC/G.2035), 1998. www

53 La introducción de mecanismos de mercado en la investigación agropecuaria y su financiamiento: cambios y transformaciones recientes, César Morales, Red de desarrollo agropecuario, (LC/L.1181 y Corr.1) 1999. www

54 Procesos de subcontratación y cambios en la calificación de los trabajadores, Anselmo García, Leonard Mertens y Roberto Wilde, Red de reestructuración y competitividad, (LC/L.1182-P) Nº de venta: S.99.II.G.23 (US\$10.00), 1999. www

55 La subcontratación como proceso de aprendizaje: el caso de la electrónica en Jalisco (México) en la década de los noventa, Enrique Dussel, Red de reestructuración y competitividad, (LC/L.1183-P) Nº de venta: S.99.II-G.16 (US\$ 10.00), 1999. www

56 Social dimensions of economic development and productivity: inequality and social performance, Beverley Carlson, Restructuring and Competitiveness Network, (LC/L.1184-P) Sales No: E.99.II.G.18, (US\$10.00), 1999. www

57 Impactos diferenciados de las reformas sobre el agro mexicano: productos, regiones y agentes, Salomón Salcedo Red de desarrollo agropecuario, (LC/L.1193-P) $\mathrm{N}^{\circ}$ de venta: S.99.II.G.19 (US\$10.00), 1999. www

58 Colombia: Un CANálisis de su competitividad internacional, José Luis Bonifaz y Michael Mortimore, Red de inversiones y estrategias empresariales, (LC/L.1229-P) Nº de venta S.99.II.G.26 (US\$10.00), 1999.

59 Grupos financieros españoles en América Latina: Una estrategia audaz en un difícil y cambiante entorno europeo, Alvaro Calderón y Ramón Casilda, Red de inversiones y estrategias empresariales, (LC/L.1244-P) $\mathrm{N}^{\circ}$ de venta S.99.II.G.27 (US\$10.00), 1999. www

60 Derechos de propiedad y pueblos indígenas en Chile, Bernardo Muñoz, Red de desarrollo agropecuario, (LC/L.1257P) $\mathrm{N}^{\circ}$ de venta: S.99.II.G.31 (US\$10.00), 1999. www

61 Los mercados de tierras rurales en Bolivia, Jorge A. Muñoz, Red de desarrollo agropecuario, (LC/L.1258-P) $\mathrm{N}^{\circ}$ de venta S.99.II.G.32 (US\$10.00), 1999. www

62 México: Un CANálisis de su competitividad internacional, Michael Mortimore, Rudolph Buitelaar y José Luis Bonifaz, Red de inversiones y estrategias empresariales (LC/L.1268-P) No de venta S.00.II.G.32 (US\$10.00), 2000. www

63 El mercado de tierras rurales en el Perú, Volumen I: Análisis institucional, Eduardo Zegarra Méndez, Red de desarrollo agropecuario, (LC/L.1278-P) Nº de venta: S.99.II.G.51 (US\$10.00), 1999 www y Volumen II: Análisis económico Eduardo Zegarra Méndez, Red de desarrollo agropecuario, (LC/L.1278/Add.1-P) $\mathrm{N}^{\circ}$ de venta: S.99.II.G.52 (US\$10.00), 1999. www

64 Achieving Educational Quality: What Schools Teach Us, Beverley A. Carlson, Restructuring and Competitiveness Network, (LC/L.1279-P) Sales N E.99.II.G.60 (US\$10.00), 2000. www

65 Cambios en la estructura y comportamiento del aparato productivo latinoamericano en los años 1990: después del “Consenso de Washington”, ¿Qué?, Jorge Katz, Red de reestructuración y competitividad, LC/L.1280-P) N de venta S.99.II.G.61 (US\$10.00), 1999. www

66 El mercado de tierras en dos provincia de Argentina: La Rioja y Salta, Jürgen Popp y María Antonieta Gasperini, Red de desarrollo agropecuario, (LC/L.1300-P) $\mathrm{N}^{\circ}$ de venta S.00.II.G.11 (US\$10.00), 1999. www

67 Las aglomeraciones productivas alrededor de la minería: el caso de la Minera Yanacocha S.A., Juana R. Kuramoto Red de reestructuración y competitividad, (LC/L1312-P) $\mathrm{N}^{\circ}$ de venta S.00.II.G.12 (US\$10.00), 2000. www 
68 La política agrícola en Chile: lecciones de tres décadas, Belfor Portilla R., Red de desarrollo agropecuario (LC/L.1315-P) No de venta S.00.II.G.6 (US\$10.00), 2000. www

69 The Current Situation of Small and Medium-Sized Industrial Enterprises in Trinidad \& Tobago, Barbados and St.Lucia, Michael Harris, Restructuring and Competitiveness Network, (LC/L.1316-P) Sales No E.00.II.G.85 (US\$10.00), 2000. www

70 Una estrategia de desarrollo basada en recursos naturales: Análisis cluster del complejo de cobre de la Southern Perú, Jorge Torres-Zorrilla, Red de reestructuración y competitividad, (LC/L.1317-P) No de venta S.00.II.G.13 (US\$10.00), 2000. www

71 La competitividad de la industria petrolera venezolana, Benito Sánchez, César Baena y Paul Esqueda, Red de reestructuración y competitividad, (LC/L.1319-P) No de venta S.00.II.G.60 (US\$10.00), 2000. www

72 Trayectorias tecnológicas en empresas maquiladoras asiáticas y americanas en México, Jorge Alonso, Jorge Carrillo y Oscar Contreras, Red de reestructuración y competitividad, (LC/L.1323-P) No de venta S.00.II.G.61 (US\$10.00), 2000. www

73 El estudio de mercado de tierras en Guatemala, Jaime Arturo Carrera, Red de desarrollo agropecuario, (LC/1325-P) $\mathrm{N}^{\mathrm{o}}$ de venta S.00.II.G.24 (US\$10.00), 2000. www

74 Pavimentando el otro sendero: tierras rurales, el mercado y el Estado en América Latina, Frank Vogelgesang, Red de desarrollo agropecuario, (LC/L1341-P) No de venta S.00.II.G.19 (US\$10.00), 2000. www

75 Pasado y presente del comportamiento tecnológico de América Latina, Jorge Katz, Red de reestructuración y competitividad (LC/L.1342-P) No de venta S.00.II.G.45 (US\$10.000), 2000. www

76 El mercado de tierras rurales en la República Dominicana,, Angela Tejada y Soraya Peralta, Red de desarrollo agropecuario (LC/L.1363-P) No de venta S.00.II.G.53 (US\$10.00), 2000. www

77 El mercado de tierras agrícolas en Paraguay, José Molinas Vega, Red de desarrollo agropecuario, (LC/L.1367-P) N ${ }^{\circ}$ de venta S.00.II.G.145 (US\$10.00), 2000. www

78 Pequeñas y medianas empresas industriales en Chile, Cecilia Alarcón y Giovanni Stumpo, Red de reestructuración y competitividad, (LC/L.1368-P) No de venta S.00.II.G.72 (US\$10.00), 2000. www

79 El proceso hidrometalúrgico de lixiviación en pilas y el desarrollo de la minería cuprífera en Chile, Jorge Beckel, Red de reestructuración y competitividad, (LC/L.1371-P) No de venta S.00.II.G.50 (US\$10.00), 2000. www

80 La inversión extranjera en México, Enrique Dussel Peters, Red de inversiones y estrategias empresariales, (LC/L.1414-P) No de venta S.00.II.G.104 (US\$10.00), 2000. www

81 Two decades of adjustment and agricultural development in Latin America and the Caribbean, Max Spoor Agricultural and Rural Development, (LC/L.1380-P) Sales N E.00.II.G.54 (US\$10.00), 2000. www

82 Costa Rica: Sistema Nacional de Innovación, Rudolph Buitelaar, Ramón Padilla y Ruth Urrutia-Alvarez, Red de reestructuración y competitividad, (LC/L.1404-P) $\mathrm{N}^{\circ}$ de venta S.00.II.G.71 (US\$10.00), 2000. www

83 La formación de un cluster en torno al turismo de naturaleza sustentable en Bonito, MS, Brasil, Red de desarrollo agropecuario (LC/L.1633-P No de venta E.01.II.G. 172 (US\$10.00), 2001.www

84 The transformation of the American Apparel Industry: Is NAFTA a curse or blessing, Gary Gereffi, Investment and Corporate Strategies, (LC/L.1420-P) Sales No S.00.II.G.103, (US\$10.00), 2000. www

85 Perspectivas y restricciones al desarrollo sustentable de la producción forestal en América Latina, Maria Beatriz de Albuquerque David, Violette Brustlein y Philippe Waniez, Red de desarrollo agropecuario, (LC/L.1406-P) $\mathrm{N}^{\circ}$ de venta S.00.II.G.73 (US\$10.00), 2000. www

86 Mejores prácticas en políticas y programas de desarrollo rural: implicancias para el caso chileno, Maximiliano Cox, Red de desarrollo agropecuario, (LC/L.1509-P) $\mathrm{N}^{\mathrm{o}}$ de venta S.00.II.G.47) (US\$10.00), 2000. www

87 Towards a theory of the small firm: theoretical aspects and some policy implications, Marco R. Di Tommaso y Sabrina Dubbini, Restructuring and Competitiveness Network, (LC/L.1415-P) Sales N E.00.II.G.86 (US\$10.00), 2000. www

88 Desempeño de las exportaciones, modernización tecnológica y estrategias en materia de inversiones extranjeras directas en las economías de reciente industrialización de Asia. Con especial referencia a Singapur Sanjaya Lall, Red de inversiones y estrategias empresariales, (LC/L.1421-P) No de venta S.00.II.G.108 (US\$10.00), 2000. www

89 Mujeres en la estadística: la profesión habla, Beverly Carlson, Red de reestructuración y competitividad, (LC/L.1436-P) Nº de venta S.00.II.G.116 (US\$10.00), 2000. www

90 Impacto de las políticas de ajuste estructural en el sector agropecuario y agroindustrial: el caso de Argentina, Red de desarrollo agropecuario, G. Ghezán, M. Materos y J. Elverdin, (LC/L.1618-P). No de venta S.01.II.G.158 (US\$10.00), 2001. www

91 Comportamento do mercado de terras no Brasil, Red de desarrollo agropecuario, G. Leite da Silva, C. Afonso, C. Moitinho (LC/L.1484-P) No de venta S.01.II.G.16 (US\$10.00), 2000. www

92 Estudo de caso: o mercado de terras rurais na regiao da zona da mata de Pernambuco, Brasil, M. dos Santos Rodrigues y P. de Andrade Rollo, Volumen I, Red de desarrollo agropecuario, (LC/L.1447-P) $N^{\circ}$ de venta S.00.II.G.127 (US\$10.00), 2000 www y Volumen II, M. dos Santos Rodrigues y P. de Andrade Rollo, Red de desarrollo agropecuario (LC/L.1447/Add.1-P) No de venta S.00.II.G.128 (US\$10.00), 2000. www 
93 La participación de pequeños productores en el mercado de tierras rurales en El Salvador, H. Ever, S. Melgar, M.A. Batres y M. Soto, Red de desarrollo agropecuario, (LC/L.1448-P) No de venta S.00.II.G.129 (US\$10.00), 2000. www

94 El impacto de las reformas estructurales en la agricultura colombiana, Santiago Perry, Red de desarrollo agropecuario (LC/L.1449-P) Nº de venta S.00.II.G.130 (US\$10.00), 2000. www

95 Costa Rica: el nuevo marco regulatorio y el sector agrícola, Luis Fernando Fernández Alvarado y Evelio Granados Carvajal, Red de desarrollo agropecuario (LC/L.1453-P) No de venta S.00.II.G.133 (US\$10.00), 2000. Www

96 Cuero, calzado y afines en Chile, László Kassai, Red de reestructuración y competitividad (LC/L. 1463-P) N ${ }^{0}$ de venta S.00.II.G.143 (US\$10.00) 2000. www

97 La pobreza rural una preocupación permanente en el pensamiento de la CEPAL, Pedro Tejo, Red de desarrollo agropecuario, (LC.L.1454-P) No de venta S.00.II.G.134 (US\$10.00), 2000. www

98 Incidencia de las reformas estructurales sobre la agricultura boliviana, Fernando Crespo Valdivia, Red de desarrollo agropecuario, (LC/L.1455-P) Nº de venta S.00.II.G.135 (US\$10.00), 2000. www

99 Mudanças estruturais na agricultura brasileira: 1980-1998 boliviana, Guilherme Leite da Silva Dias y Cicely Moitinho Amaral, Red de desarrollo agropecuario, (LC/L.1485-P) No de venta S.01.II.G.17 (US\$10.00), 2001. Www

100 From Industrial Economics to Digital Economics: An Introduction to the Transition, Martin R.Hilbert, Restructuring and Competitiveness Network Sales, (LC/L.1497-P) Sales N E.01.II.G.38 (US\$10.00) www

101 Las nuevas fronteras tecnológicas: promesas, desafíos y amenazas de transgénicos, César Morales, Red de desarrollo agropecuario, (LC/L. 1590-P) No de venta S.01.II.G.132 (US\$10.00) 2001.

102 El mercado vitivinícola mundial y el flujo de inversión extranjera a Chile, Sebastian Vergara, Red de reestructuración y competitividad, (LC/L. 1589-P) $\mathrm{N}^{\mathrm{o}}$ de venta S.01.II.G.133 (US\$ 10.00) 2001. WwW

103 Regímenes competitivos sectoriales, productividad y competitividad internacional, Red de reestructuración y competitividad Jorge Katz y Giovanni Stumpo (LC/L.1578-P) No de venta S.01.II.G.120 (US\$10.00), 2001. Www

104 Latin America on its Path into the Digital Age: Where Are We?, Martin R.Hilbert, Restructuring and Competitiveness Network, (LC/L 1555-P) Sales Nº E.01.II.G.100 (US\$ 10.000), 2001.www

105 Estrategia de desarrollo de clusters basados en recursos naturales: el caso de la bauxita en el norte de Brasil, Jorge Chami Batista, Red de reestructuración y competitividad, (LC/L.1570-P) N ${ }^{0}$ de venta S.01.II.G.113 (US\$ 10.00) 2001. WwW

106 Construcción de ambientes favorables para el desarrollo de competencias laborales: tres estudios sectoriales, Red de reestructuración y competitividad, Mónica Casalet, (LC/L.1573-P) $\mathrm{N}^{\mathrm{o}}$ de venta S.01.II.G.116 (US\$ 10.00), 2001.www

107 La competitividad internacional y el desarrollo nacional: implicancias para la política de IED en América Latina. Michael Mortimore, Sebastián Vergara, Jorge Katz, Red de reestructuración y competitividad, (LC/L.1586-P) N ${ }^{0}$ de venta S.01.II.G.130 (US\$ 10.00), 2001. www

108 América Latina en el proceso de internacionalización de las empresas finlandesas, Kent Wilska, Ville Tourunen, Red de reestructuración y competitividad,.(LC/L. 1599-P) $\mathrm{N}^{\mathrm{o}}$ de venta S.01.II.G.140 (US\$ 10.00), 2001.www

109 Colombia: Alcances y Lecciones de su experiencia en Reforma Agraria,, Alvaro Balcazar, Nelson López, Martha Lucía Orozco y Margarita Vega, Red de desarrollo agropecuario (LC/L.1602-P), $\mathrm{N}^{\mathrm{o}}$ de venta S.01.II.G.142 (US\$ 10.00), 2001. Www

110 El mercado de tierras en México, Roberto Escalante, Red de desarrollo agropecuario (LC/L.1604-P), $\mathrm{N}^{\mathrm{o}}$ de venta S.01.II.G.144 (US\$ 10.00), 2001. www

111 Fusiones y adquisiciones transfronterizas en México durante los años noventa, Celso Garrido, Red de desarrollo agropecuario (LC/L.1622-P), $\mathrm{N}^{\mathrm{o}}$ de venta S.01.II.G.161 (US\$10.00), 2001.www

112 El turismo rural en Chile. Experiencias de agroturismo en las Regiones del Maule, La Araucanía y Los Lagos, MartineDirven y Jorge Shaerer, Red de desarrollo agropecuario (LC/L 1621-P), $\mathrm{N}^{\mathrm{o}}$ de venta S.01.II G 160 (US\$ 10.00), 2001. www

113 Informe marco jurídico nacional e internacional sobre inversión extranjera directa en Chile, Felipe Lopeandia, Red de reestructuración y competitividad (LC/L.1623-P) $\mathrm{N}^{\mathrm{o}}$ de venta S.00.II.G.163 (US\$10.00) 2001. Www

114 Education and the labour market in Latin America, Beverly A. Carlson, Red de reestructuración y competitividad, (LC/L. 1631-P) $\mathrm{N}^{\mathrm{o}}$ de venta E.00.II.G.169 (US\$10.00) 2000.www

115 Programas de apoyo a las micro, pequeñas y medianas empresas en México, 1995-2000, Gilberto García y Víctor Paredes, Red de reestructuración y competitividad, (LC/L.1639-P) No de venta S.01.II.G.177 (US\$10.00) 2001. WWW

116 Políticas de competitividade industrial no Brasil, 1995-2000, Regis Bonelli, Red de reestructuración y competitividad, (LC/L.1641-P) Nº de venta S.01.II.G.181 (US\$10.00) 2001.www

117 Mercado de trabajo y formación de recursos humanos en tecnología de la información en Brasil. ¿Encuentro o desencuentro?, Lidia Micaela Segre y Clevi Elena Rapkiewicz, Red de reestructuración y competitividad, (LC/L.1658-P) No de venta S.01.II.G.192 (US\$10.00) 2001.

118 Los derechos de propiedad intelectual en el mundo de la OMC, Jacqueline Abarza, Jorge Katz, Red de reestructuración y competitividad (LC/L.1666-P) No de venta S.01.II.G.200 (US\$10.00) 2000. Www

119 La dinámica de oferta y demanda de competencias en un sector basado en el conocimiento en Argentina, Red de reestructuración y competitividad, (LC/L.1696-P) Nº de venta S.02.II.G.8 (US\$10.00) 2002. 
120 Innovación tecnológica y perfeccionamiento de las pequeñas y medianas empresas en la República Federal de Alemania: Incentivos y financiamiento, Jörg Meyer-Stamer y Frank Wältring, Red de reestructuración y competitividad (LC/L.1709-P) No de venta S.02.II.G.16 (US\$10.00) 2002.

121 Microfinanzas en países pequeños de América Latina: Bolivia, Ecuador y El Salvador, Francesco Bicciato, Laura Foschi, Elisabetta Bottato y Filippo Ivardi Ganapini, Red de reestructuración y competitividad (LC/L.1710-P) $N^{\circ}$ de venta S.02.II.G.17 (US\$10.00) 2002.

122 Acceso a tecnología después de las reformas estructurales: la experiencia de las pequeñas y medianas empresas en Brasil, Chile y México, Marco Dini, Red de reestructuración y competitividad (LC/L.1738-P), $\mathrm{N}^{\circ}$ de venta S.02.II.G.50 (US\$10.00) 2002. Www

123 Pequeñas y medianas empresas industriales y política tecnológica: el caso mexicano de las tres últimas década, Mauricio de Maria y Campos, Red de reestructuración y competitividad (LC/L.1743-P), Nº de venta S.02.II.G.55 (US\$10.00) 2002. www

124 Fatores de competitividade e barreiras ao crescimento no pólo de biotecnologia de Belo Horizonte, Pablo Fajnzylber, Red de reestructuración y competitividad (LC/L.1754-P), Nº de venta S.02.II.G.66 (US\$10.00) 2002. www

125 Adquisición de tecnología, aprendizaje y ambiente institucional en las PYME: el sector de las artes gráficas en México, Marco Dini, Juan Manuel Corona y Marco A. Jaso Sánchez, Red de reestructuración y competitividad (LC/L.1755-P), N ${ }^{\circ}$ de venta S.02.II.G.67 (US\$10.00) 2002.

126 Las PYME y los sistemas de apoyo a la innovación tecnológica en Chile, Marcelo Monsalves, Red de reestructuración y competitividad (LC/L.1756-P), $\mathrm{N}^{\mathrm{o}}$ de venta S.02.II.G.68 (US\$10.00) 2002. www

127 As políticas de apoio à geração e difusão de tecnologias para as pequenas e médias empresas no Brasil, Marisa dos Reis Botelho y Maurício Mendonça, Red de reestructuración y competitividad (LC/L.1757-P), No de venta S.02.II.G.69 (US\$10.00) 2002. Www

128 El acceso de los indígenas a la tierra en los ordenamientos jurídicos de América Latina: un estudio de casos. Volúmen II, José Aylwin, Red de desarrollo agropecuario (LC/L 1767-P), $\mathrm{N}^{\mathrm{o}}$ de venta S.02.II G.82 (US\$ 10.00), 2002.

129 Structural reforms, technological gaps and economic development. A Latin American Perspective. Mario Cimoli and Jorge Katz, Red de reestructuración y competitividad (LC/L1775.-P), No de venta S.02.II.G.89 (US\$ 10.00) 2002.

- Readers wishing to obtain the above publications can do so by writing to the following address: ECLAC, Division of Production, Productivity and Management, Casilla 179-D, Santiago de Chile. Some issues may not be available.

- Publications available for sale should be ordered from the Distribution Unit, ECLAC, Casilla 179-D, Santiago, Chile, Fax (562) 210 2069, publications@eclac.cl.

Name:

Activity:

Address:

Postal code, city, country:

Tel.:

Fax: E.mail address: 